\title{
Self-Assembling Peptides and Carbon Nanomaterials Join Forces for Innovative Biomedical Applications
}

\author{
Petr Rozhin ${ }^{1}$, Costas Charitidis ${ }^{2}$ (D) and Silvia Marchesan $1,3, *$ (D) \\ 1 Chemical and Pharmaceutical Sciences Department, University of Trieste, 34127 Trieste, Italy; \\ petr.rozhin@phd.units.it \\ 2 School of Chemical Engineering, National Technical University of Athens, Iroon Polytechneiou 9, Zografou, \\ 15780 Athens, Greece; charitidis@chemeng.ntua.gr \\ 3 INSTM, Unit of Trieste, 34127 Trieste, Italy \\ * Correspondence: smarchesan@units.it
}

check for

updates

Citation: Rozhin, P.; Charitidis, C.;

Marchesan, S. Self-Assembling

Peptides and Carbon Nanomaterials Join Forces for Innovative Biomedical Applications. Molecules 2021, 26, 4084 https://doi.org/10.3390/

molecules 26134084

Academic Editor: Carlo Diaferia

Received: 8 June 2021

Accepted: 2 July 2021

Published: 4 July 2021

Publisher's Note: MDPI stays neutral with regard to jurisdictional claims in published maps and institutional affiliations.

Copyright: (c) 2021 by the authors. Licensee MDPI, Basel, Switzerland. This article is an open access article distributed under the terms and conditions of the Creative Commons Attribution (CC BY) license (https:// creativecommons.org/licenses/by/ $4.0 /)$.

\begin{abstract}
Self-assembling peptides and carbon nanomaterials have attracted great interest for their respective potential to bring innovation in the biomedical field. Combination of these two types of building blocks is not trivial in light of their very different physico-chemical properties, yet great progress has been made over the years at the interface between these two research areas. This concise review will analyze the latest developments at the forefront of research that combines self-assembling peptides with carbon nanostructures for biological use. Applications span from tissue regeneration, to biosensing and imaging, and bioelectronics.
\end{abstract}

Keywords: self-assembly; peptides; amyloids; carbon dots; graphene; carbon nanotubes; fullerene; nanostructures; biomaterials; hydrogels

\section{Introduction \\ 1.1. Self-Assembling Peptides}

Supramolecular systems based on self-assembling peptides have become a very popular topic of investigation for multidisciplinary research [1,2]. There are many reasons that render these building blocks very attractive. First of all, amino acids feature a very large chemical diversity that has been further extended with the introduction of numerous non-natural derivatives; thus, making it possible to virtually encode any kind of functional group into a peptide [3,4]. Secondly, their preparation can be conveniently attained by a variety of methods, with the modular solid-phase synthesis standing out for simplicity, also for the non-expert, as well as ease of purification [5]. Thirdly, short peptide sequences can exert part of the functionalities displayed by complex proteins, thus, allowing for their biomimicry using much simpler, and often more robust, molecules [6]. Fourth, the choice of encoding a desired function within a supramolecular architecture opens the door to smart systems that respond to external stimuli with assembly/disassembly cycles, with consequent on/off switching of the encoded function. This bioinspired feature is very attractive for biomedical applications $[7,8]$, spanning from the development of smart antimicrobials [9], to advanced vehicles for therapeutics [8,10] and protein [11] delivery. The additional advantages of inherent biodegradability and biocompatibility render self-assembling peptides ideal building blocks also for vaccine development [12], imaging [13,14], biomaterials design [15], wound healing [16], and cancer therapy [17,18].

Self-assembling peptides are often derived from amyloids, which have been recognized as important biotechnological tools, besides their relevance in physiological and pathological contexts [19]. Amyloid proteins and peptides display a typical cross- $\beta$ structure with molecular backbones being perpendicular to the long axis of the fibrils and interacting with each other through ordered hydrogen bonding, while amino acid side-chains typically engage in steric zippers of a hydrophobic nature [20]. Among the amyloid-derived 
short peptides, the most popular building block used for self-assembly is diphenylalanine [21]. This minimalistic building block with a strong self-association propensity into nanotubes (Figure 1) was identified through a reductionist approach from the amyloid $\beta$-peptide sequence [22]. Since then, a large variety of derived motifs have been used to design self-organizing derivatives [23]. Several reviews have appeared in the last year on self-assembling short peptides for biomedical applications [24,25], especially drug delivery $[26,27]$ and tissue engineering [28], also owing to their ability to mimic the extracellular matrix [29]. More specifically, their use has been reviewed as microgels [30], antimicrobials [31], for angiogenesis [32], in gene therapy [33], to treat metabolic syndromes [34] and gastrointestinal diseases [35], to regenerate bone [36] and conductive tissues [37] such as nerves [38], to develop bioelectronics [39] and vaccines [40]. Therefore, in this review we will not analyze in detail these highly promising systems.

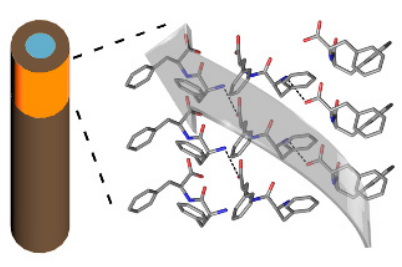

(a)

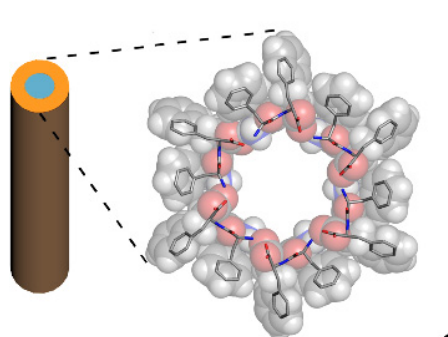

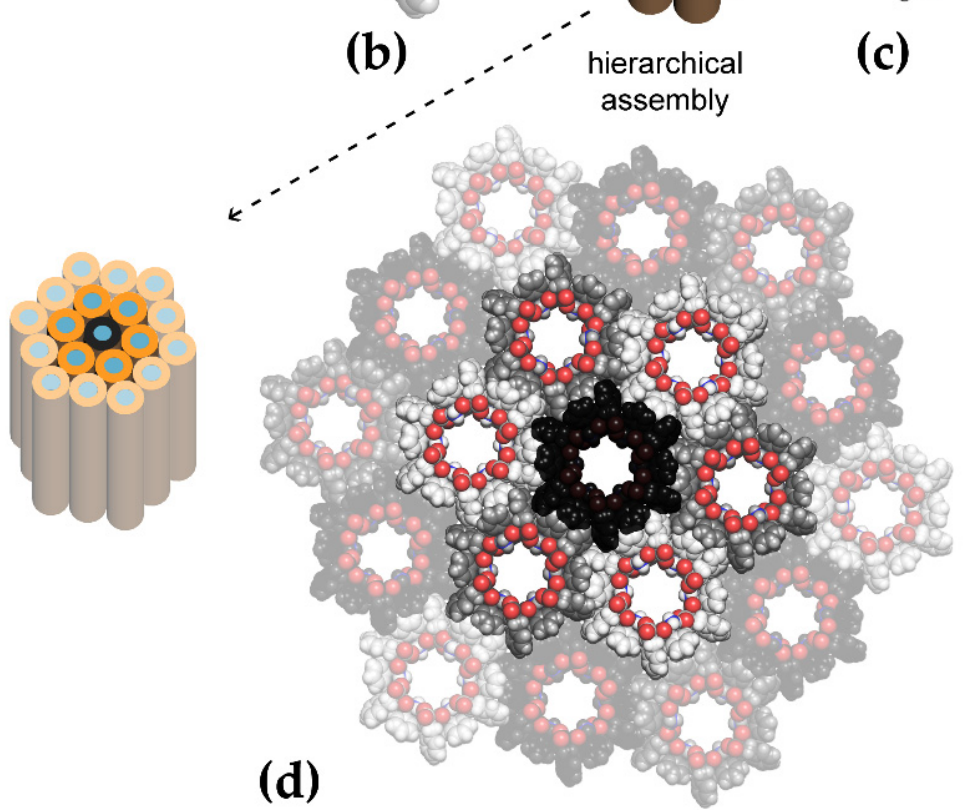

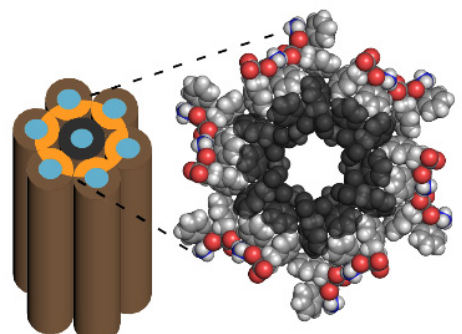

(c)

Figure 1. Schematic representation of amyloid-derived diphenylalanine self-assembled nanotubes from single-crystal XRD data [41]. (a) Side-view of the dipeptide stacks along the nanotube, (b-d) top-view of the (b) individual nanotubes, and (c,d) their progressive bundling into microtubes. Adapted from [42] under a Creative Commons license (https: / / creativecommons.org/licenses/by/4.0/, accessed on 8 June 2021).

However, peptide-based systems display also certain limitations; therefore, the research has been very active to develop composite [43] or hybrid [44] nanostructures and materials with additional components to ameliorate their features and introduce new properties. Numerous examples have been reported to date and with a great variety of chemical components, such as polymers [45], polysaccharides [46], nucleic acids [47], inorganic nanoparticles [48,49], polyoxometalates [50], metal-organic cages [51], and more.

\subsection{Carbon Nanomaterials}

A specific type of additives that deserves a detailed discussion comprises the family of carbon nanostructures (Figure 2). They all share the common feature of being composed 
by carbon atoms, which are, in the majority of cases, $\mathrm{sp}^{2}$ hybridized and inter-connected in a honeycomb lattice [52]. Nevertheless, they can be extremely diverse both in terms of structure and morphology, thus, in their reactivity and physico-chemical properties. They comprise 0D fullerenes [53], nano-onions [54], and luminescent nanodots [55]. Onedimensional carbon nanotubes (CNTs) [56] feature a tubular morphology, while graphenebased materials [57] can be considered 2D. Other examples include clusters of nanocones termed nanohorns (CNHs) [58] and nanodiamonds (NDs), which feature a large amount of $\mathrm{sp}^{3}$-hybridized carbon atoms [59] and are promising for various biomedical uses [60].

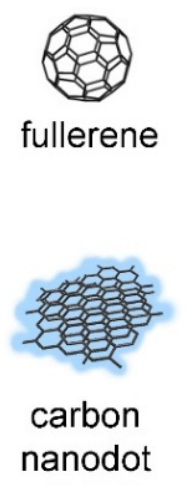

(CND)

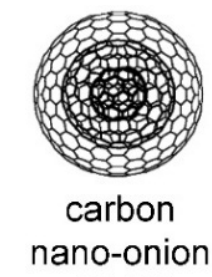

(CNO)

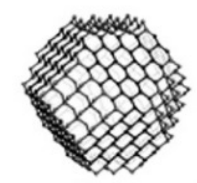

nanodiamond (ND)

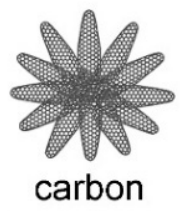

nanohorn

$(\mathrm{CNH})$

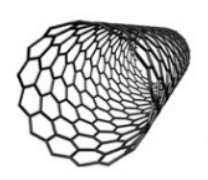

carbon

nanotubes

(CNTs)

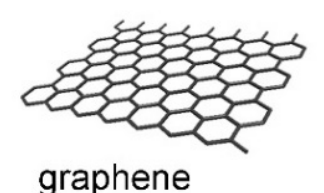

graphene

Figure 2. Carbon nanomaterials (not to scale), reproduced from [61] under a Creative Commons license (https: / / creativecommons.org/licenses/by/4.0/, accessed on 8 June 2021). The nano-onion is reproduced from [62], copyright $@ 1995$ with permission from Elsevier.

All these diverse carbon nanostructures have been widely studied, yet it is not straightforward to predict which is the ideal candidate based on the type of intended application. This challenge is amplified in biologically relevant contexts, which are characterized by a high-level of chemical complexity [63-67]. To this end, it is key to study their different ability to interact with biomolecules and develop a protein corona on their surface [68] that will influence their ability to elicit an immune response [69,70], as well as their biodegradation [71,72] and biodistribution [73].

Despite their morphological diversity, they do share certain common features, including a low density, high mechanical strength, good electronic conductivity, and they provide the opportunity to further tailor their properties upon chemical functionalization [74]. In addition, carbon nanostructures display a high-surface area and hydrophobic nature that can be exploited to non-covalently load high levels of bioactive molecules, as widely applied in drug delivery [75]. As a result, they have attracted great interest for their innovative potential in areas of unmet clinical need [74,76], such as oncology [77], infections [78], and tissue engineering [79], especially for conductive nerve $[80,81]$ and cardiac [82,83] tissues, but also bone [84]. Their potential applications in sensing [85] and, generally, in clinical applications [86] are also widely studied.

Nevertheless, today there are still concerns regarding possible side-effects from the use of carbon nanomaterials $[87,88]$, and their great heterogeneity renders the task even more challenging to assess [89]. A useful approach to address this issue is to develop unified standards for their classification, which is a complex task that is being tackled by various committees [90]. A general framework for a reliable risk assessment approach to develop nanotechnology responsibly is a common objective for societal welfare [91]. Innovative ways for more efficient data management [92] and inclusion of modern in silico methods, such as machine learning to make the most out of large datasets, hold the key to tackle this type of unresolved issues [93]. 


\subsection{Combination of Self-Assembling Peptides and Carbon Nanomaterials}

The combination of self-assembling peptides with carbon nanomaterials can provide a very interesting opportunity to innovate in the biomedical sector, given their highly diverse properties. On one hand, peptides are ideal components for biomimicry, to exert bioactivity [94] and favorably interact with water [95]. On the other, carbon nanomaterials conductivity and mechanical resilience can provide additional properties to peptide-based systems [96]. Furthermore, synergy can be created by leveraging on their very different chemical nature. For instance, one of the main limitations of carbon nanomaterials is their hydrophobic nature and tendency to aggregate that may be alleviated through chemical functionalization [97]. Alternatively, the amphiphilic nature of self-assembling peptides can be convenient to enhance carbon nanomaterials' dispersibility in water $[66,98,99]$. Ordered oligoglycines, for instance, were shown to coat oxidized CNTs or GO thanks to non-covalent interactions between the carboxylic acid groups on the carbon nanomaterials and the $\mathrm{N}$-terminus of the peptides, with potential applications in conductive tissue regeneration [100].

In addition, peptides can be used for active targeting [101], cell penetration [102], to direct biodegradation [103], as fluorescent probes [104], and so on. However, the very different chemical nature of these two types of components renders their combination quite a challenge [105], and as a result this area of research is still underexplored. Furthermore, in the case of self-assembling peptides, it is possible that the presence of carbon nanomaterials can have detrimental effects on their supramolecular behavior. This represents a further challenge for exploiting their interaction in useful ways. In certain cases, the inhibitory effect can be useful, for instance to target fibrillation of pathological amyloids [67,106]. In this concise review, we will, thus, delineate how self-assembling peptides and carbon nanomaterials can indeed join forces to innovate in the biomedical sector, and we will focus on the very latest research efforts of the last few years in this inspiring area.

\section{Research on the Interaction between Self-Assembling Peptides and Nanocarbons}

Despite the fact that carbon nanomaterials are a large group that comprises many different types of structures and morphologies as shown in Figure 2, the majority of recent studies that combine them with self-assembling peptides concerns graphene-based materials, and, to a lesser extent, CNTs and carbon dots. Over the years, research pertaining to the design of nanostructures and self-assembling building blocks has achieved great advances, so that we have witnessed a progressive shift from 2D [107] to 3D-architectural complexity [108]. This section will describe the latest developments in this area, dividing the most recent reports based on the type of nanocarbon, and following a progression from $0 \mathrm{D}$ materials (i.e., fullerenes and carbon dots) to $1 \mathrm{D}$ components (i.e., CNTs), to the $2 \mathrm{D}$ graphene-based materials (e.g., graphene, graphene oxide or GO, and reduced graphene oxide or rGO). In some cases, more than one carbon nanostructure has been combined with self-assembling peptides in multi-component systems [109-111]. Recent examples are reported in Table 1, following the same progressive order from $0 \mathrm{D}$ to $1 \mathrm{D}$ and 2D carbon nanomaterials.

Table 1. Recent examples of studies on the interaction between self-assembling peptides and carbon nanostructures.

\begin{tabular}{|c|c|c|c|c|}
\hline Carbon Nanostructure & Peptide & Material & Application & Ref. \\
\hline Fullerene & $\mathrm{A} \beta(1-40), \mathrm{A} \beta(1-42)$ & Solution & $\begin{array}{l}\text { Amyloidosis } \\
\text { inhibition }\end{array}$ & [112] \\
\hline Fullerene & $\mathrm{A} \beta(1-42)$ & Solution & $\begin{array}{l}\text { Amyloidosis } \\
\text { inhibition }\end{array}$ & [113] \\
\hline Fullerene & Cyclopeptide nanotube & Solution & Bioelectronics & [114] \\
\hline Fullerene & Fmoc-Phe-Phe & Hydrogel & Antibacterials & [115] \\
\hline Carbon dots & D-Leu-L-Phe-L-Phe & Hydrogel & $\begin{array}{l}\text { Biomaterial, } \\
\text { biosensing }\end{array}$ & [116] \\
\hline
\end{tabular}


Table 1. Cont.

\begin{tabular}{|c|c|c|c|c|}
\hline Carbon Nanostructure & Peptide & Material & Application & Ref. \\
\hline Carbon dots & $\mathrm{A} \beta(1-42)$ & Solution & $\begin{array}{l}\text { Amyloidosis } \\
\text { inhibition }\end{array}$ & {$[117,118]$} \\
\hline Carbon dots & $\mathrm{A} \beta(1-42)$ & Solution & Biosensing & [119] \\
\hline Carbon dots & Biofilm amyloids & Solution & Antibacterials & [120] \\
\hline Carbon dots & RGDAEAKAEAKYWYAFAEAKAEAKRGD & Solution & Theranostics & [121] \\
\hline Carbon dots, $\mathrm{GO}^{1}$ & AEAKAEAKYWYAFAEAKAEAK & Solution & Biosensing & [111] \\
\hline Carbon dots, CNTs, GO ${ }^{1}$ & $A \beta_{33-42}$ & Solution & $\begin{array}{l}\text { Amyloidosis } \\
\text { inhibition }\end{array}$ & [67] \\
\hline CNHs, CNTs, $\mathrm{GO}^{1}$ & L-Leu-D-Phe-D-Phe & Hydrogel & $\begin{array}{l}\text { Biomaterial, drug } \\
\text { delivery }\end{array}$ & {$[66]$} \\
\hline CNTs & EFK8 & Hydrogel & Tissue regeneration & {$[98]$} \\
\hline CNTs & RADA16-I & Hydrogel & Tissue regeneration & [122] \\
\hline CNTs & $\begin{array}{l}\text { Boc- } \beta^{3}(\mathrm{R}) \mathrm{Phe}-\beta^{3}(\mathrm{R}) \mathrm{Phe}-\mathrm{OH} \\
\text { Boc- } \gamma^{4}(\mathrm{R})-\mathrm{Phe}-\gamma^{4}(\mathrm{R}) \mathrm{Phe}-\mathrm{OH}\end{array}$ & Fibrils & Tissue regeneration & [123] \\
\hline CNTs, graphene & Trp, Phe & Solution & Bioelectronics & [124] \\
\hline CNTs, $\mathrm{GO}^{1}$ & $\mathrm{C}_{8} \mathrm{H}_{16}\left(-\mathrm{CH}_{2}-\mathrm{NH}-\mathrm{Gly}_{5}\right)_{2} \cdot 2 \mathrm{HCl}$ & Film & Tissue regeneration & [100] \\
\hline $\mathrm{CNTs}_{\mathrm{T}} \mathrm{GO}^{1}$ & Fmoc-Tyr-OH, Fmoc-Tyr(Bzl)-OH & Hydrogel & Drug delivery & {$[125]$} \\
\hline Graphene & Phe-Phe & Solution & Biosensing & [126] \\
\hline Graphene & IMVTESSDYSSY & Film & Biosensing & [127] \\
\hline Graphene & $\begin{array}{l}\text { HSSYWYAFNNKT } \\
\text { IMVTESSDYSSY }\end{array}$ & Film & Biosensing & [128] \\
\hline Graphene & YGAGAGAY, EGAGAGAE, RGAGAGAR & Solution & Biosensing & [129] \\
\hline Graphene & LLVFGAKMLPHHGA & Scaffold & Tissue regeneration & {$[130]$} \\
\hline $\mathrm{GO}^{1}$ & Phe-Phe & Solution & Biosensing & [131] \\
\hline $\mathrm{GO}^{1}$ & Phe-Phe, Tyr-Tyr & Solution & Theranostics & {$[132]$} \\
\hline $\mathrm{GO}^{1}$ & CLVPRGSC, CRGC & Solution & Biosensing & {$[133]$} \\
\hline $\mathrm{GO}^{1}$ & $\mathrm{C}_{16} \mathrm{CO}-\mathrm{KKFF}$ & Membrane & Antibacterials & [134] \\
\hline $\mathrm{GO}^{1}$ & FEFKFEFK & Hydrogel & Tissue regeneration & [135] \\
\hline $\mathrm{GO}^{1}$ & AEAKAEAKYWYAFAEAKAEAK & Solution & Tissue regeneration & [136] \\
\hline $\mathrm{GO}^{1}$ & $\begin{array}{c}\mathrm{N}_{3}-\mathrm{KKPPPPKGPLGVRGC-CONH} \\
\mathrm{N}_{3}-\mathrm{KKPPPPKGPLGVRGA-CONH}_{2} \\
\mathrm{~N}_{3}-\mathrm{KKPPPPKAAPFC-CONH} \\
\end{array}$ & Solution & Biosensing & {$[137]$} \\
\hline $\mathrm{GO}^{1}$ & $\begin{array}{l}\text { Block copolymer polypeptide } \\
\text { PBLG-b-PDMS-b-PBLG }\end{array}$ & Gel & Tissue regeneration & [138] \\
\hline $\mathrm{GO}^{1}, \mathrm{rGO}^{2}$ & VEVKVEVK, FEFKFEFK, FEFEFKFE & Hydrogel & Tissue regeneration & [139] \\
\hline $\mathrm{rGO}^{2}$ & $\begin{array}{l}\text { Boc-Trp-PABA-OMe, } \\
\text { Boc-Phe-PABA-OMe, } \\
\text { Boc-Phg-PABA-OMe }\end{array}$ & Hydrogel & Tissue regeneration & {$[140]$} \\
\hline $\mathrm{rGO}^{2}$ & Polylysine, polyglutamate & Dispersion & Tissue regeneration & [141] \\
\hline
\end{tabular}

${ }^{1}$ GO-graphene oxide. ${ }^{2}$ rGO-reduced graphene oxide.

\subsection{Fullerenes}

Fullerenes are hollow, spherically shaped structures with a very interesting affinity for electrons and their transport that renders them attractive for applications in energy and photocatalysis [142], as well as photodynamic therapy [143]. In medicine, fullerenes have 
been widely studied as antioxidants [144,145], antimicrobials [146], and vehicles for drug delivery $[147,148]$. Fullerenes, and in particular $\mathrm{C}_{60}$, have been studied also for their ability to interfere with amyloid aggregation [106]. However, fullerenes' poor solubility in water is a limiting factor for their biological application, for which more hydrophilic derivatives are preferred, such as fullerenols that carry hydroxyl groups [149]. A recent study compared in silico the ability of $\mathrm{C}_{60}, \mathrm{C}_{60}(\mathrm{OH})_{6}$ and $\mathrm{C}_{60}(\mathrm{OH})_{12}$ to inhibit the fibrillation of amyloid beta $(\mathrm{A} \beta)$ peptides, concluding that $\mathrm{C}_{60}(\mathrm{OH})_{6}$ led to the best inhibitory performance thanks to its balanced amphipathic character, which allowed hydrophobic interactions as well as hydrogen bonding with the peptide backbone [112]. Another hydrophilic $\mathrm{C}_{60}$ derivative, 1,2-(dimethoxymethano)fullerene, was studied for the same purpose as it demonstrated to be a fibrillation inhibitor for $A \beta$ in silico [113].

Hydrophobic interactions have been used also to allow the encapsulation of $\mathrm{C}_{60}$ within supramolecular peptide nanotubes formed through stacking of cyclopeptide derivatives (Figure 3). This type of hybrid nanostructure was envisaged for potential use in drug delivery or electronic applications. $C_{70}$ could not be efficiently encapsulated with the same strategy presumably due to its bigger size [114]. Conversely, when self-assembling peptide cavitands were used for fullerene encapsulation, both $\mathrm{C}_{60}$ or $\mathrm{C}_{70}$ could be suitable guests [150].

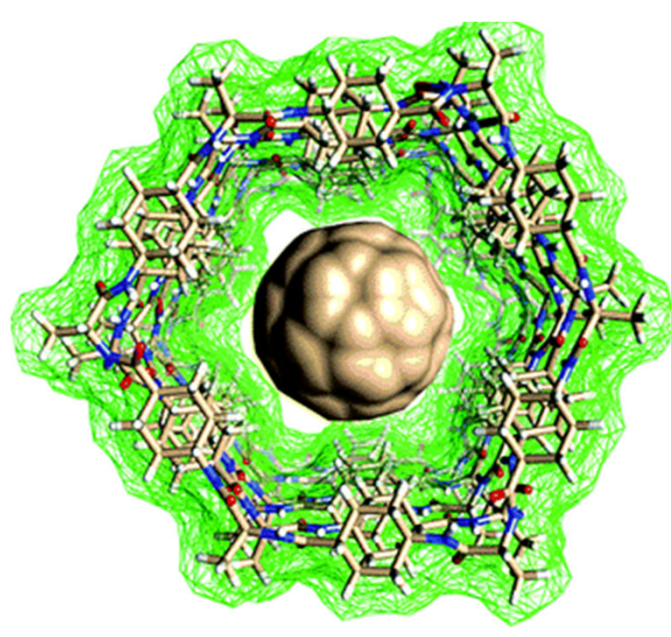

(a)

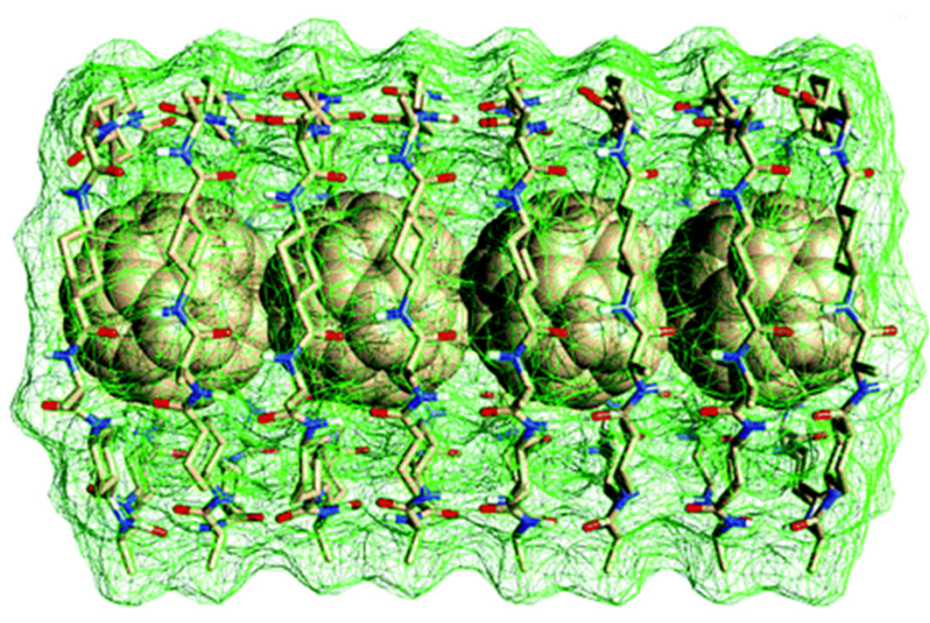

(b)

Figure 3. (a) Top-view and (b) side-view of a computer-assisted model of $\mathrm{C}_{60}$ encapsulated in the inner cavity of supramolecular nanotubes arising from the stacking of cyclopeptides. Adapted from [114] published by the Royal Society of Chemistry under a Creative Commons license (https:/ / creativecommons.org/licenses/by/4.0/, accessed on 8 June 2021).

Peptides can indeed be very convenient to enhance fullerenes' solubility in water and direct their supramolecular behavior, whilst maintaining their electronic properties and resulting antioxidant activity, as demonstrated through covalent conjugation [151,152]. Alternatively, a non-covalent approach can be envisaged, for instance by embedding fullerenes within the hydrogel matrix formed by self-assembling peptides; the resulting hybrid material could be envisaged for photodynamic antibacterial therapy, because of the fullerenes' well-established electronic properties with the additional benefit of the injectable matrix formed due to the presence of the peptide [115].

\subsection{Carbon Dots}

Carbon dots are a more recent type of carbon nanomaterials that can be conveniently prepared through top-down or bottom-up approaches [153], also starting from small molecules in a green manner [61], and have very promising photoluminescence and biocompatibility profiles for applications in medicine [154,155]. They are widely studied, especially for biosensing applications, given their tunable optoelectronic properties [156]. 
Carbon dots have demonstrated in some cases to have detrimental effects on the self-assembly of amyloid peptides, although it is possible to turn this phenomenon into an advantage, for instance by hindering hierarchical bundling of amyloids and stabilizing instead the formation of individual fibrils to attain a more homogeneous and luminescent hydrogel (Figure 4) [116].
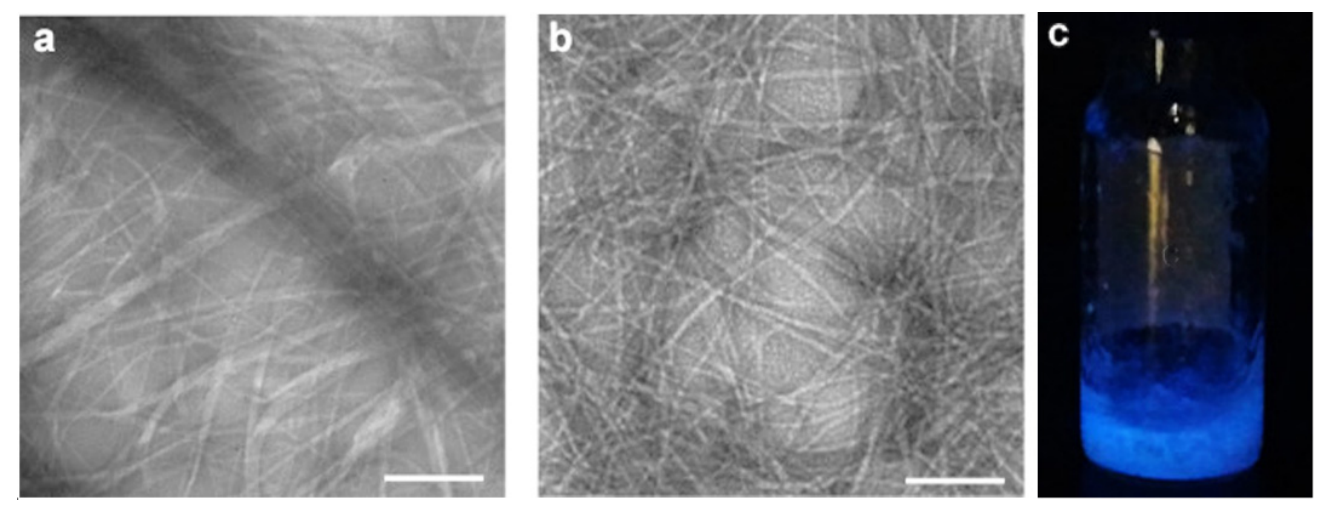

Figure 4. Supramolecular hydrogels from a self-assembling tripeptide (a) without or $(\mathbf{b}, \mathbf{c})$ with carbon dots. (a,b) Transmission electron microscopy (TEM) micrographs reveal that presence of the dots yields a homogeneous population of peptide fibrils (b), as it inhibits the hierarchical bundling of fibrils into heterogeneously sized fibers that occurs with the peptide alone (a). The hybrid gel is luminescent as seen under a UV light (c). Scale bar $=200 \mathrm{~nm}$. Adapted from [116].

Alternatively, they can be used to inhibit pathological amyloid aggregation, although to this end, GO was shown to be more effective [67], yet clearly the performance could depend on a plethora of physicochemical properties of the specific nanomaterials of choice, including not only the size and morphology, but also the type and density of functional groups as well as the experimental conditions. For instance, dost can be effective for this application, as shown for nitrogen-doped carbon dots displaying intense photoluminescence at $550 \mathrm{~nm}$, when excited at $420 \mathrm{~nm}$, that originated from the $\mathrm{n} \rightarrow \pi^{*}$ transition of N-groups. The amine and imine groups on their surface effectively chelated $\mathrm{Cu}$ divalent cations, thus, preventing $\mathrm{Cu}(\mathrm{II})$-induced $\mathrm{A} \beta$ aggregation as well as the amyloid aggregation in the absence of copper. Moreover, irradiation of the dots with a blue LED generated radical oxygen species that oxidized the amyloid peptide, thus, providing yet another means to inhibit its aggregation [117]. This type of approach could be further improved through the carbon dots' functionalization with an aptamer for specific targeting, and through preparation from different precursors to attain red-light responsiveness, for better tissue penetration in vivo (Figure 5) [118].

Graphene carbon dots have been proposed as imaging agents to monitor amyloid fibrillation. One advantage is that they display tunable emission that depends on the excitation wavelength. In one study, excitation at $400 \mathrm{~nm}$ was shown to be particularly favorable to yield intense emission at $500 \mathrm{~nm}$ that was quenched by the presence of the amyloid $\beta$ peptide monomer, whilst not by its fibrils. The authors ascribed the phenomenon to the ability of amyloid $\beta$, only in the monomer state, to favorably interact with the graphene quantum dots for an excited-state electron energy transfer that resulted in luminescence quenching [119]. However, it is worth noting that amyloids present intrinsic fluorescence that is independent from the peptide sequence [157]. It has been ascribed to the refolding from helical to $\beta$-sheet structures and it covers the whole visible region $(400-650 \mathrm{~nm})$, finding potential applications for bioimaging in vivo [14]. 


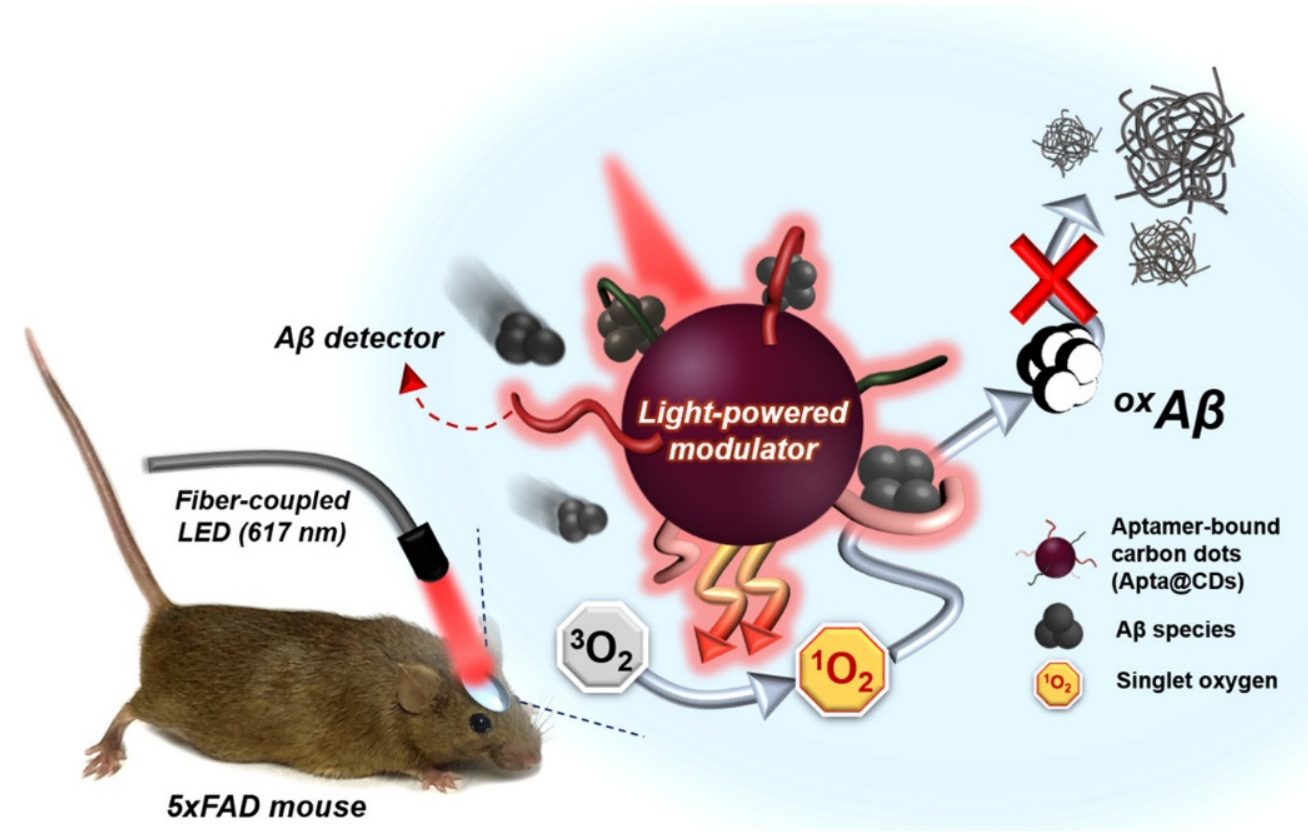

Figure 5. Carbon dot-mediated photo-modulated $A \beta$ aggregation inhibition in vivo. The aptamer-functionalized carbon dots (Apta@CDs) capture A $\beta$ species in neurophysiological conditions, and, under red-light irradiation, they generate ${ }^{1} \mathrm{O}_{2}$ to chemically and irreversibly denature $\mathrm{A} \beta$ peptides for effective inhibition of neurotoxic amyloid aggregation. Reproduced with permission from Chung, Y. J. et al., ACS Nano [118], ( ) 2021 American Chemical Society.

Amyloids occur in a variety of pathologically-relevant contexts that go well beyond neurodegenerative diseases, and are recurrent also in prokaryotes [158]. For instance, Staphylococcus aureus mature biofilms are rich in amyloids, and graphene quantum dots were shown to effectively disaggregate them, possibly acting on the nuclei and altering their structure; thus, hindering further elongation into fibrils [120].

Alternatively, amyloid peptides can be bound to carbon dots to attain nanostructured materials for theranostics. As an example, the peptide sequence RGDAEAKAEAKYWYAFAEAKAEAKRGD was chosen as it contained (1) the RGD bioactive motif to target cancer cells, (2) the YWYAF motif for selective binding onto graphenic surfaces, and (3) the EAK motif for self-assembly into nanofibers. In this manner, the peptide elongated nanostructures bound to graphene quantum dots that were probed in vitro for the targeting and imaging of cancel cells [121].

Finally, carbon dots have been combined with GO and peptide nanofibers for the biosensing of hydrogen peroxide. In this case, the peptide sequence was designed to provide aromatic binding sites for both the dots and GO. This approach served to provide further stability to the ternary system, as well as an additional layer to hamper GO aggregation and favor the adsorption of electrolytes for electrochemical sensing and the diffusion of reagents [111].

\subsection{Carbon Nanotubes (CNTs)}

Carbon nanotubes feature a tubular morphology and can display one, two, or more graphitic walls [159]. Depending on how the graphene sheet is rolled into the tubular structure, different chirality and electronic properties arise [160]. High-purity sorted CNTs find a myriad of innovative applications, especially in sensing [161], nanoelectronics [162], and even implantable biosensors [163].

Interestingly, CNTs can be spun into macroscopic fibers with various degrees of CNT alignment, hence, varying electromechanical properties [164]. Their extraordinary properties in terms of conductivity, low density, high tensile strength, and so on, rendered them very attractive components for the development of innovative flexible, and even wearable, electronics [165]. Furthermore, convenient and green protocols have been developed to 
functionalize CNT fibers in the gas phase, with virtually no waste production and the possibility to fine-tune their hydrophilicity for use in water or ionic liquids, as needed for the intended application [166].

The development of biohybrids based on self-assembling biomolecules and CNTs is gaining momentum [167]. In particular, the similar anisotropic morphology of CNTs and peptide fibrils can favor the formation of hybrid materials, whereby the two components are intimately connected, and the resulting hydrogels display enhanced mechanical properties relative to the systems without CNTs $[66,98]$. Furthermore, CNTs' dispersibility can be enhanced through non-covalent coating by self-assembling peptides that typically display an amphipathic nature [168]. Sometimes new properties, such as a self-healing behavior, can emerge from such favorable interactions [66]. The binding of amyloid peptides onto the CNTs' surface is governed by several factors, including CNT curvature as shown by molecular dynamics' studies [169]. The interactions between aromatic amino acids, such as tryptophan and phenylalanine, which are recurrent residues in self-assembling peptides, have been studied by molecular dynamics for their ability to yield stable supramolecular hybrid materials [124]. Alternatively, self-assembling peptides can also be covalently anchored onto the CNT's surface, in this manner, upon the addition of free peptides, supramolecular dendritic structures were obtained, for potential applications in tissue engineering [123].

There are several potential applications for these systems, including smart materials that release their cargo upon application of specific stimuli, such as near-infrared light irradiation that exploits CNT photo-thermal energy conversion [125]. Other uses of this type of materials include tissue regeneration, as shown on peripheral nerves, with promising levels of myelination when coupled with electrical stimuli (Figure 6) [122]. Alternatively, aggregation-induced emission of self-assembling peptide derivatives that also act as CNT dispersants could find potential applications in sensing [99], especially if suitable conjugation strategies are adopted to maximize the performance of the resulting systems for optical detection [170]. Furthermore, CNTs have been proposed for photoacoustic imaging in vivo, which could be applied to tumor tissues through their conjugation with targeting moieties, such as cyclic Arg-Gly-Asp to target integrin proteins that were overexpressed by cancer cells [171].

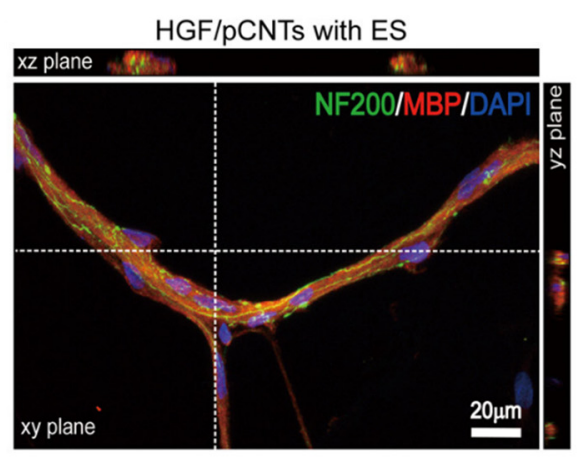

(a)

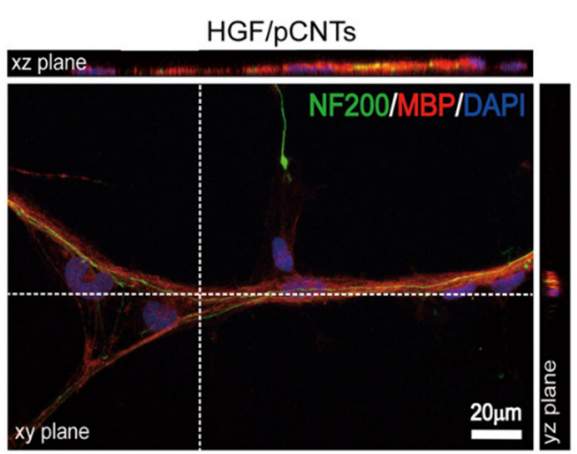

(b)

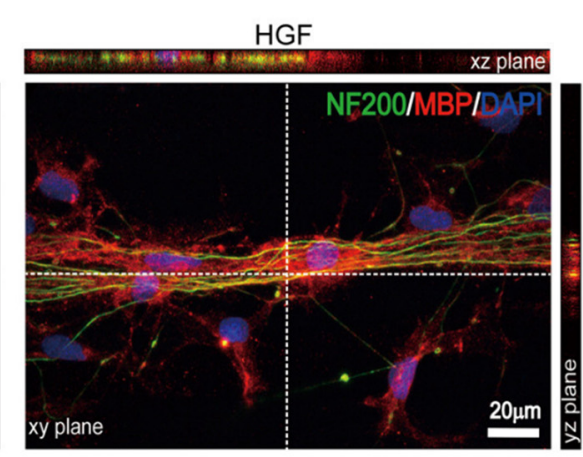

(c)

Figure 6. Axon myelination after a 30-day neuron cultivation under different conditions: (a) self-assembling peptide (HGF), pristine CNTs (pCNTs), and electrical stimulation (ES); (b) HGF and pristine CNTs; (c) HGF alone. Neurons are stained in green (NF200), myelin in red (MBP), and cell nuclei in blue (DAPI). Adapted with permission from He, L. et al., ACS Appl. Mater. Interfaces [122], copyright (C) 2021, American Chemical Society.

\subsection{Graphene-Based Materials}

Graphene-based materials come in different form and size and their classification has been reviewed [172]. Graphene's unique physicochemical properties, high conductivity and tensile strength, and low density have attracted great interest for biological applications $[173,174]$. As can be seen from Table 1, graphene oxide is possibly the most studied 
type of derivative to generate biomaterials scaffold, in light of its higher dispersibility in water relative to graphene. Conversely, for biosensing and bioelectronics applications, graphene is preferred for its superior electron conductivity.

De novo design of peptide sequences for optimized adsorption and self-assembly onto the graphene's surface is a challenging task, since the binding energy is determined by cooperative effects that are not simply the sum of each amino acid contribution [175]. Compared to polyaromatic units, such as pyrene that can engage in efficient and ordered $\pi-\pi$ stacking, peptides display weaker binding onto graphene, yet they are being studied for their ability to self-organize onto graphene and modify its electronic properties for sensing applications [128]. In particular, self-assembled diphenylalanine nanotubes are widely investigated and can form onto the surface of graphene, despite the fact that binding of the peptides onto the carbon nanomaterial's surface does alter the hydrogen bonding pattern of the assemblies [126]. When self-assembling peptide gelators and graphene oxide are successfully combined together, the mechanical properties of the resulting materials are improved $[66,138]$.

\subsubsection{Sensing Applications}

Glycine-alanine repeating units proved useful in the design of self-assembling peptides that could form stable coatings onto exfoliated graphite for biosensing applications, as demonstrated through inclusion of biotin for streptavidin detection (Figure 7) [129]. In another work, for the same purpose, the peptide sequence IMVTESSDYSSY was used for its ability to bind to graphenic substrates forming a self-assembled monolayer, and was mutated to display biotin [127]. However, typically these are proof-of-concept studies, while the most studied self-assembling peptide for more advanced sensing applications is diphenylalanine, which yields nanotubes, as previously shown in Figure 1. For instance, aligned semiconducting peptide nanotube-graphene oxide composites allowed to enhance the surface-enhanced Raman spectroscopy (SERS) relative to GO alone, allowing the nanomolar detection of glucose and nucleobases [131].

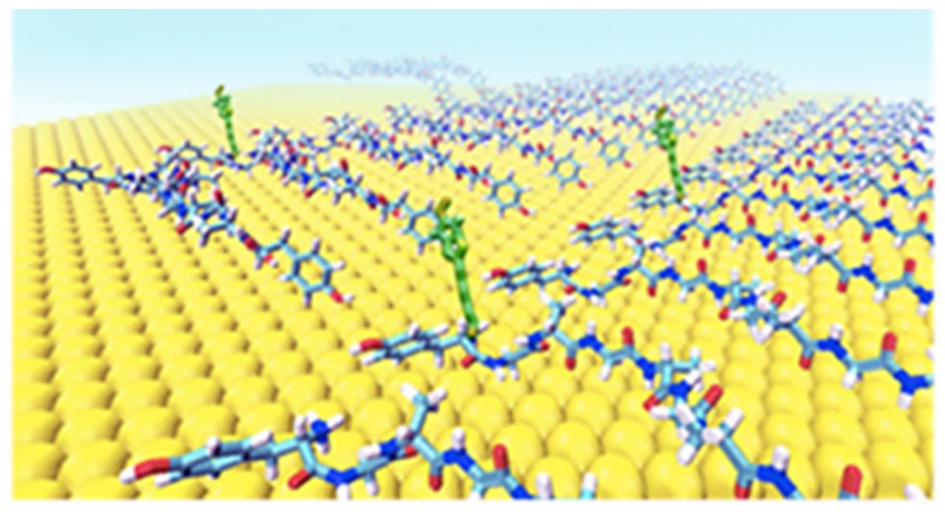

(a)

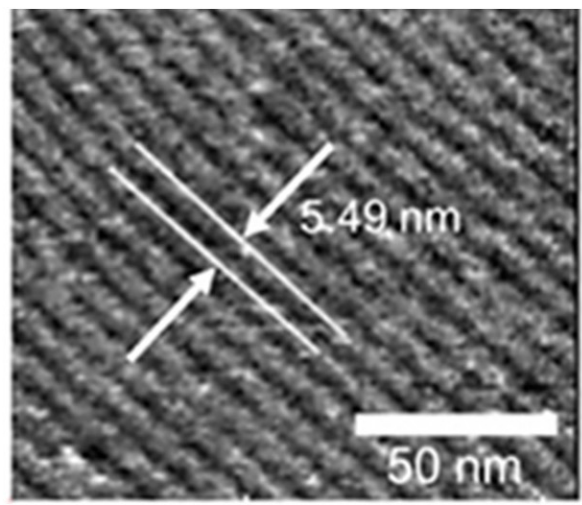

(b)

Figure 7. (a) Self-assembling peptides based on glycine-alanine repeating units form hydrogen-bonded ordered $\beta$-sheets to coat substrates (yellow) for biosensing, thanks to the inclusion of a biotin probe (green). (b) Atomic force microscopy shows the peptide-ordered arrays. Reproduced with permission from Li, P. et al., ACS Appl. Mater. Interfaces [129], copyright (C) 2021 American Chemical Society.

GO was also combined with diphenylalanine-peptide nanotubes to develop a sensor, in this case using a graphite electrode, due to the conductivity of the components. Subsequent inclusion of a single-stranded DNA sequence complementary to a target microRNA allowed for its detection through changes in impedance in the biosensor (Figure 8) with a remarkably wide linear range (10 fM-1.0 nM) and low sensing limit (8 fM) [176]. This study was designed for the quantification of microRNA-192, which is a useful target for 
oncological studies, as it is downregulated in cancer cells, of which it inhibits proliferation, migration and invasion, and promotes apoptosis [177].

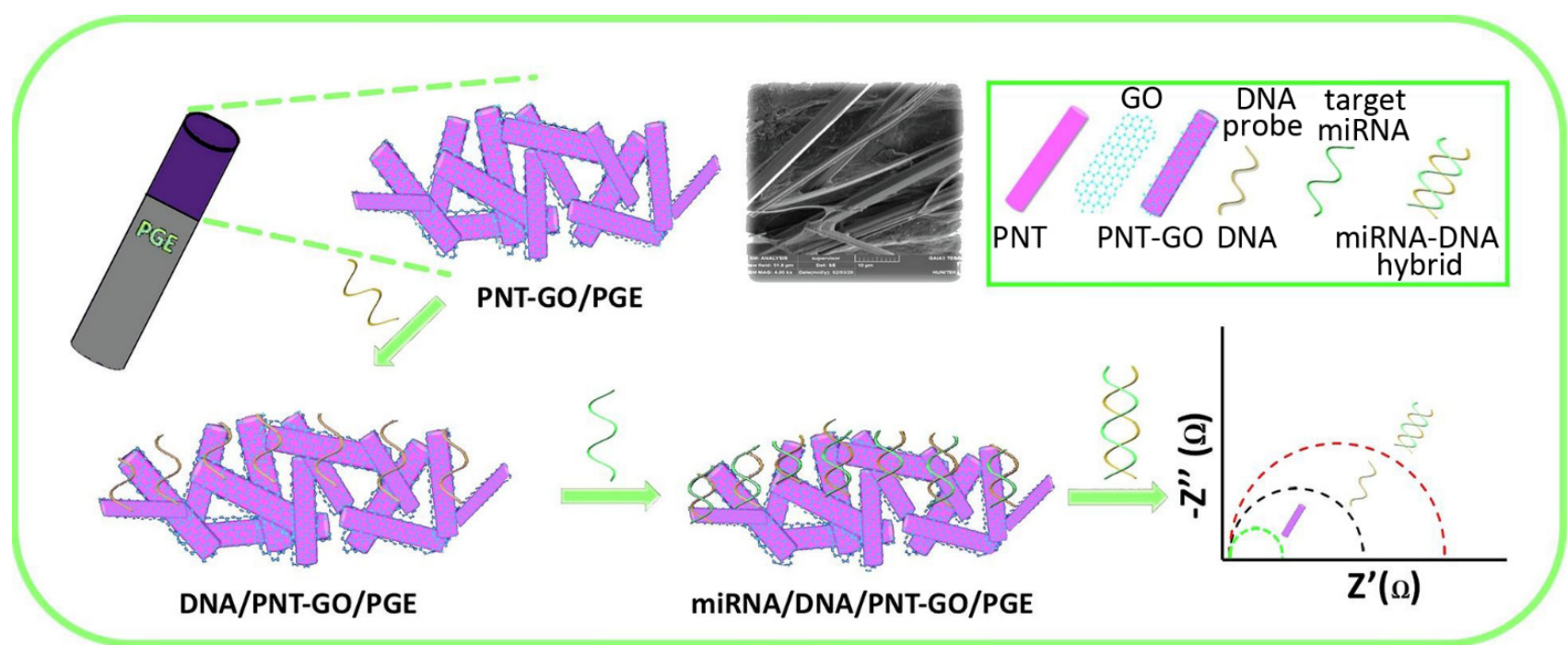

Figure 8. MicroRNA (miRNA-192) biosensor based on a pencil graphite electrode (PGE) coated with self-assembled diphenylalanine nanotubes (PNTs) and GO, onto which the addition of a single-stranded DNA probe allowed for hybridization with its complementary target miRNA sequence, and detection through changes in impedance. Adapted from [176] @ 2021 with permission from Elsevier.

In another study, azido-peptides were grafted onto GO flakes and subsequent peptide assembly led to the quenching of the nanomaterial's inherent fluorescence. The peptide sequence was designed to display a target motif that could be cleaved by matrix metalloproteinases (MMP-2). When tested in cell culture, these enzymes secreted by cells could be detected and quantified, since their enzymatic activity led to the disassembly of the nanomaterial and to the consequent switching-on of the fluorescent signal [137]. A similar concept was also developed for thrombin biosensing. In this case, GO flakes were decorated with gold nanoparticles and self-assembling peptide-displaying cleavable sites for the enzyme. As a result, in the presence of thrombin, the absorbance of the nanomaterial varied and allowed for the spectroscopic detection of the enzyme [133].

\subsubsection{Energy-Harvesting Systems for Bioelectronics}

The piezoelectric activity of diphenylalanine nanotubes has been exploited also to develop energy-harvesting systems for bioelectronics to generate charge when pressed. To this end, they are usually grown vertically aligned through evaporation of a saturated solution with a seed of molecules onto a substrate, and controlled polarization of the peptides can be attained by applying an electric field (Figure 9) [178]. Moreover, horizontal alignment onto GO flexible substrates can be achieved, thanks to a difference in wettability and an applied electrical field [179].

\subsubsection{Biomaterials for Wound Healing and Tissue Regeneration}

There is growing interest in the conjugation of antimicrobial peptides with antibacterial graphene-based materials [180], for instance for potential applications in wound healing. To this end, one-pot ring-opening copolymerization of lysine and leucine $\mathrm{N}$ carboxyanhydride into self-assembling polypeptides was used as a simple strategy to yield self-assembling antimicrobials that were also conjugated to graphene to yield hierarchical structures [181]. Antibacterial membranes were developed by combining a self-assembling palmitoyl tetrapeptide with GO flakes [134]. Self-assembling diphenylalanine was also reported to exert antimicrobial activity through bacterial membrane disruption [182], and was studied in combination with GO flakes for potential applications in nanomedicine [132]. 


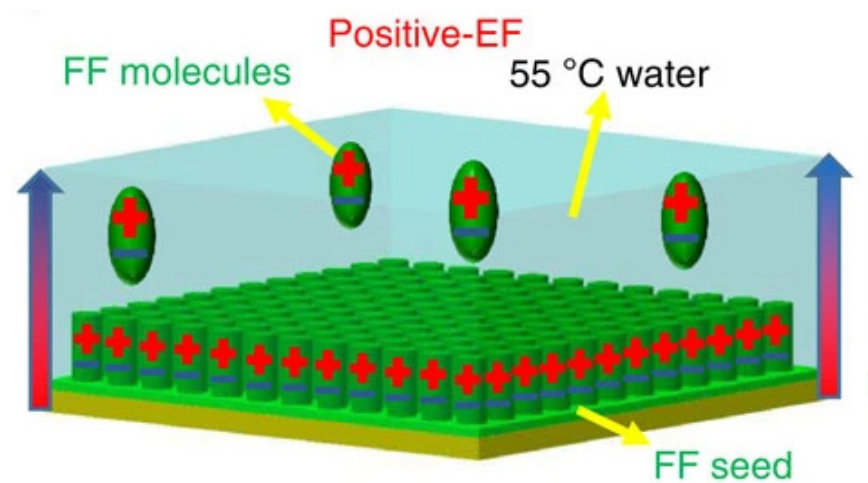

(a)

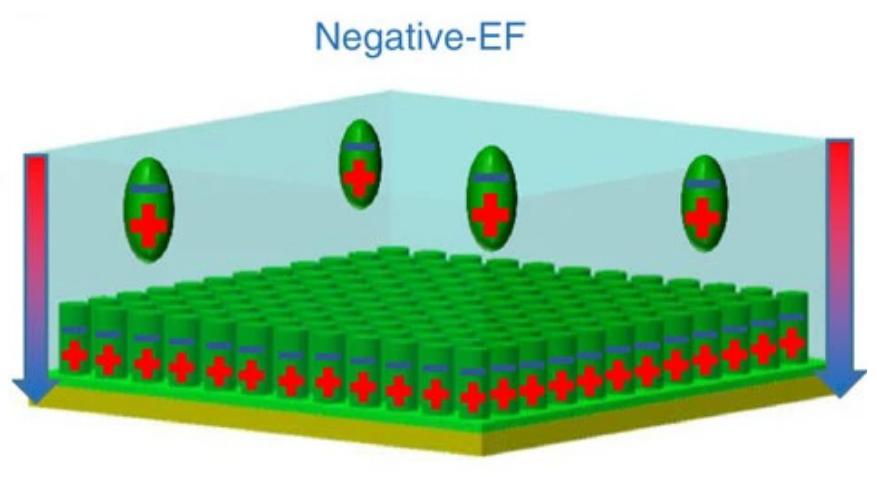

(b)

Figure 9. Diphenylalanine (FF) self-assembly into vertically aligned nanotubes can be attained with controlled polarization upon application of a positive (a) or negative (b) electric field (EF), to construct piezoelectric devices for bioelectronics. Adapted from [178] under a Creative Commons license (https:/ / creativecommons.org/licenses/by/4.0/, accessed on 8 June 2021).

Applications of peptide-graphene supramolecular systems are wide, and they could be envisaged also for the regeneration of conductive tissues thanks to the electronic properties imparted especially by the carbon nanostructure [140]. To this end, reduced graphene oxide flakes were grafted with bioactive peptides to yield layer-by-layer supramolecular scaffolds held together by electrostatic interactions. The scaffolds allowed for enhanced adhesion and neurite outgrowth in PC12 cells cultured with electrical stimulation [141].

This type of material has been envisaged also for intervertebral disc repair, as the GO acted as nanofiller to reinforce the hydrogel formed by the self-assembling FEFKFEFK sequence. Interestingly, at $\mathrm{pH}=4$ and a low concentration of peptide, electrostatic interactions were attractive and the viscous modulus of the hydrogel was increased. However, at a high concentration of peptide, electrostatic interactions can be absent or repulsive, and the elastic modulus was decreased. At $\mathrm{pH}=7$, there was an increase in elastic modulus at all concentrations, as hydrophobic interactions dominated over the electrostatic ones, which were removed upon conditioning with culture media [135]. The same peptide was also tested, together with another two sequence variant, for self-assembly in the presence of graphene-based materials as nanofillers to provide scaffolds that were tested for the culture of stem cells. Moreover, in this case, the intimate interaction between peptides and nanocarbon flakes were key determinants for the viscoelastic properties of the final systems, with a positive effect arising from hydrophobic interactions and variable outcomes arising from electrostatic forces [139].

Inorganic-organic bio-hybrids have been developed for tissue regeneration too. For instance, the self-assembling peptide AEAKAEAKYWYAFAEAKAEAK was used to provide nanofibers which, combined with GO flakes, favored the nucleation and growth of hydroxyapatite crystals for bone tissue regeneration [136]. Recently, 2D sheets arising from the self-assembly of the LLVFGAKMLPHHGA peptide sequence were combined with GO and hydroxyapatite to yield porous and light-weight scaffolds for the reconstruction of bones [130].

Hydrogels obtained from resilin-like polypeptides also displayed enhanced mechanical resilience upon inclusion of GO flakes [183], as did those formed from a heterochiral tripeptide [66]. Alternatively, graphene can be used as a nanofiller for supramolecular hydrogels arising from the self-organization of peptide derivatives, as shown for a pseudopeptide, yielding biomaterials with a thermoresponsive and thixotropic behavior [184].

\subsubsection{Drug Release}

In certain cases, a very interesting supramolecular behavior can arise from the interaction between self-assembling peptides and graphenic surfaces. Racemic crystals from biomolecules, such as self-assembling phenylalanine, were found to maintain a straight 
geometry when adsorbed onto a flat surface; conversely, enantiopure analogues underwent twisting [124]. This type of phenomenon could be exploited for the enantioselective drug adsorption and release, as shown for ibuprofen and a self-assembling phenylalanine derivative that formed right-handed helical nanoribbons on the surface of GO. UV-irradiation could then be used as a trigger for drug release, following the switching of helicity to left-handed (Figure 10) [185].

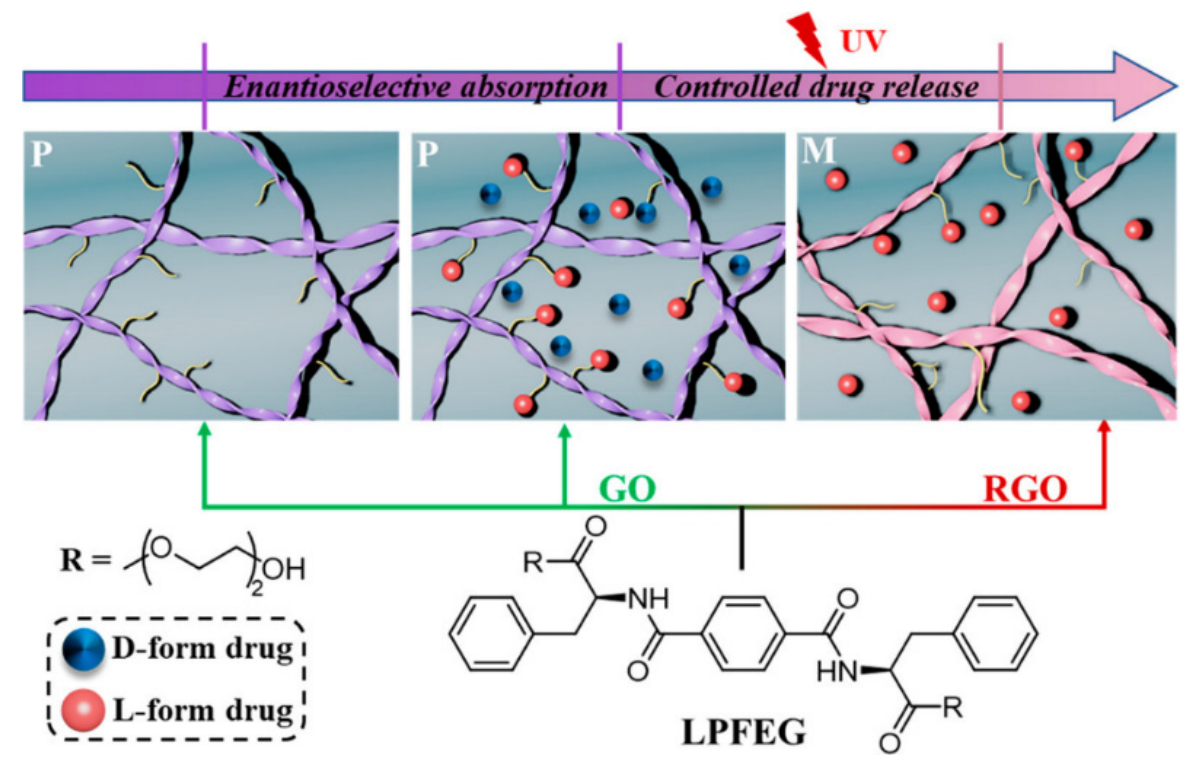

Figure 10. Photo-triggered ibuprofen release from self-assembled helical nanoribbons on the surface of GO flakes. Reprinted with permission from Zhang, Y. et al., ACS Nano [172] copyright (C) 2021 American Chemical Society.

\section{Conclusions}

The combination of self-assembling peptides and carbon nanostructures is a research area undergoing significant expansion. The very different chemical nature of these two components represents a technical challenge that requires a wide skillset to efficiently conjugate them in stable systems. However, it also represents an opportunity for a qualitative leap in the biomedical field, if the advantages of each component are put to good use, ideally creating synergy. While in the past the inclusion of carbon nanostructures, and especially graphene, was mainly studied with the aim to simply enhance the mechanical stability and resilience of peptide gels, in recent years a great progress towards more complex applications has been made in the biomedical field.

In particular, the electronic properties of peptide assemblies have attracted great attention also for energy-harvesting and conversion, leading to innovative approaches in the field of bioelectronics and biosensing where carbon nanostructures are already wellknown for their excellent performance. The vast majority of these studies focus on the simple diphenylalanine building block, but it is anticipated that extending the chemical diversity of peptide sequences will allow to better benefit from these biomolecules and their potential (bio)activities. However, a challenge lies in the identification of general trends to predict the physicochemical properties and supramolecular behavior of a large variety of self-assembling peptides. This class of biomolecules is well-known for its great chemical diversity which, combined with the inherent flexibility of biomolecules, renders prediction of their behavior particularly challenging. We anticipate that machine learning methods will become key for the de novo design of self-assembling peptides that favorably interact with carbon nanomaterials, thanks to the increasing growth of large datasets that are being generated for these compounds worldwide.

It is clear that, thus far, graphene-based materials represent the most studied nanocarbon type to develop systems that interface them with self-assembling peptides, followed by carbon nanotubes, and, more recently, carbon dots. This latter type of nanocarbon is 
clearly on an ascending trajectory for future applications, thanks to the small-size, tunable luminescence, and possibility for green synthesis, all of which make it highly promising for biomedical applications. Considering the emerging fluorescent properties of amyloids $[14,186]$, one can envisage further opportunities to innovate in the biomedical field from the optical applications that combine these two components into multifunctional theranostic systems for multimodal imaging. Clearly this type of application is particularly challenging to develop as it requires both interdisciplinary and multidisciplinary skills, spanning from chemistry to engineering and biology. Therefore, financial and networking support is vital to sustain the free exchange of knowledge between scientists of different backgrounds that approach this exciting area of research, to allow for progress that will benefit the society as a whole.

Author Contributions: Writing—original draft preparation, P.R.; writing—review and editing, C.C. and S.M. All authors have read and agreed to the published version of the manuscript.

Funding: Our work in the field was supported by the Italian Ministry of University and Research (MIUR) PRIN2015 project number 2015TWP83Z. This article is based upon work from COST Action EsSENce CA19118, supported by COST (European Cooperation in Science and Technology www.cost.eu, accessed on 8 June 2021).

Institutional Review Board Statement: Not applicable.

Informed Consent Statement: Not applicable.

Acknowledgments: P.R. and S.M. would like to acknowledge Manuela Bisiacchi for her technical assistance.

Conflicts of Interest: The authors declare no conflict of interest.

\section{References}

1. Levin, A.; Hakala, T.A.; Schnaider, L.; Bernardes, G.J.L.; Gazit, E.; Knowles, T.P.J. Biomimetic peptide self-assembly for functional materials. Nat. Rev. Chem. 2020, 4, 615-634. [CrossRef]

2. Lampel, A. Biology-Inspired Supramolecular Peptide Systems. Chem 2020, 6, 1222-1236. [CrossRef]

3. Ding, Y.; Ting, J.P.; Liu, J.; Al-Azzam, S.; Pandya, P.; Afshar, S. Impact of non-proteinogenic amino acids in the discovery and development of peptide therapeutics. Amino Acids 2020, 52, 1207-1226. [CrossRef]

4. Brittain, W.D.; Lloyd, C.M.; Cobb, S.L. Synthesis of complex unnatural fluorine-containing amino acids. J. Fluor. Chem. 2020, 239, 109630. [CrossRef]

5. Jaradat, D.M.M. Thirteen decades of peptide synthesis: Key developments in solid phase peptide synthesis and amide bond formation utilized in peptide ligation. Amino Acids 2018, 50, 39-68. [CrossRef] [PubMed]

6. Hamley, I.W. Small Bioactive Peptides for Biomaterials Design and Therapeutics. Chem. Rev. 2017, 117, 14015-14041. [CrossRef]

7. Ahn, W.; Lee, J.-H.; Kim, S.R.; Lee, J.; Lee, E.J. Designed protein- and peptide-based hydrogels for biomedical sciences. J. Mater. Chem. B 2021, 9, 1919-1940. [CrossRef] [PubMed]

8. Osorno, L.L.; Brandley, A.N.; Maldonado, D.E.; Yiantsos, A.; Mosley, R.J.; Byrne, M.E. Review of Contemporary Self-Assembled Systems for the Controlled Delivery of Therapeutics in Medicine. Nanomaterials 2021, 11, 278. [CrossRef] [PubMed]

9. Kurbasic, M.; Parisi, E.; Garcia, A.M.; Marchesan, S. Self-Assembling, Ultrashort Peptide Gels as Antimicrobial Biomaterials. Curr. Top. Med. Chem. 2020, 20, 1300-1309. [CrossRef]

10. Gao, J.; Zhan, J.; Yang, Z. Enzyme-Instructed Self-Assembly (EISA) and Hydrogelation of Peptides. Adv. Mater. 2020, 32, 1805798. [CrossRef]

11. Lyu, Y.; Azevedo, H.S. Supramolecular Hydrogels for Protein Delivery in Tissue Engineering. Molecules 2021, 26, 873. [CrossRef]

12. Nguyen, Q.D.; Kikuchi, K.; Maity, B.; Ueno, T. The Versatile Manipulations of Self-Assembled Proteins in Vaccine Design. Int. J. Mol. Sci. 2021, 22, 1934. [CrossRef]

13. Wang, Y.; Xia, K.; Wang, L.; Wu, M.; Sang, X.; Wan, K.; Zhang, X.; Liu, X.; Wei, G. Peptide-Engineered Fluorescent Nanomaterials: Structure Design, Function Tailoring, and Biomedical Applications. Small 2021, 17, 2005578. [CrossRef] [PubMed]

14. Apter, B.; Lapshina, N.; Lapsker, I.; Handelman, A.; Accardo, A.; Diaferia, C.; Morelli, G.; Rosenman, G. Fold-Sensitive Visible Fluorescence in $\beta$-Sheet Peptide Structures. Adv. Opt. Mater. 2021, 2002247. [CrossRef]

15. Balasco, N.; Diaferia, C.; Morelli, G.; Vitagliano, L.; Accardo, A. Amyloid-Like Aggregation in Diseases and Biomaterials: Osmosis of Structural Information. Front. Bioeng. Biotechnol. 2021, 9, 641372. [CrossRef] [PubMed]

16. Chu, B.; He, J.-M.; Liu, L.-L.; Wu, C.-X.; You, L.-L.; Li, X.-L.; Wang, S.; Chen, C.-S.; Tu, M. Proangiogenic Peptide Nanofiber Hydrogels for Wound Healing. ACS Biomater. Sci. Eng. 2021, 7, 1100-1110. [CrossRef] [PubMed]

17. Li, L.; Ma, B.; Wang, W. Peptide-Based Nanomaterials for Tumor Immunotherapy. Molecules 2021, 26, 132. [CrossRef] [PubMed] 
18. Deng, Y.; Zhan, W.; Liang, G. Intracellular Self-Assembly of Peptide Conjugates for Tumor Imaging and Therapy. Adv. Healthc. Mater. 2021, 10, 2001211. [CrossRef]

19. Ke, P.C.; Zhou, R.; Serpell, L.C.; Riek, R.; Knowles, T.P.J.; Lashuel, H.A.; Gazit, E.; Hamley, I.W.; Davis, T.P.; Fändrich, M.; et al. Half a century of amyloids: Past, present and future. Chem. Soc. Rev. 2020, 49, 5473-5509. [CrossRef]

20. Chatani, E.; Yuzu, K.; Ohhashi, Y.; Goto, Y. Current Understanding of the Structure, Stability and Dynamic Properties of Amyloid Fibrils. Int. J. Mol. Sci. 2021, 22, 4349. [CrossRef]

21. Mayans, E.; Alemán, C. Revisiting the Self-Assembly of Highly Aromatic Phenylalanine Homopeptides. Molecules 2020, $25,6037$. [CrossRef] [PubMed]

22. Reches, M.; Gazit, E. Casting metal nanowires within discrete self-assembled peptide nanotubes. Science 2003, 300, 625-627. [CrossRef] [PubMed]

23. Du, X.; Zhou, J.; Shi, J.; Xu, B. Supramolecular Hydrogelators and Hydrogels: From Soft Matter to Molecular Biomaterials. Chem. Rev. 2015, 115, 13165-13307. [CrossRef]

24. Das, A.K.; Gavel, P.K. Low molecular weight self-assembling peptide-based materials for cell culture, antimicrobial, antiinflammatory, wound healing, anticancer, drug delivery, bioimaging and 3D bioprinting applications. Soft Matter 2020, 16, 10065-10095. [CrossRef]

25. Mougin, J.; Bourgaux, C.; Couvreur, P. Elongated self-assembled nanocarriers: From molecular organization to therapeutic applications. Adv. Drug Deliv. Rev. 2021, 172, 127-147. [CrossRef]

26. Zhang, Z.; Ai, S.; Yang, Z.; Li, X. Peptide-based supramolecular hydrogels for local drug delivery. Adv. Drug Deliv. Rev. 2021, 174, 482-503. [CrossRef]

27. Diaferia, C.; Rosa, E.; Accardo, A.; Morelli, G. Peptide-based hydrogels as delivery systems for doxorubicin. J. Pept. Sci. 2021, e3301. [CrossRef]

28. Karavasili, C.; Fatouros, D.G. Self-assembling peptides as vectors for local drug delivery and tissue engineering applications. Adv. Drug Deliv. Rev. 2021, 174, 387-405. [CrossRef]

29. Da Silva, K.; Kumar, P.; Choonara, Y.E.; du Toit, L.C.; Pillay, V. Three-dimensional printing of extracellular matrix (ECM)mimicking scaffolds: A critical review of the current ECM materials. J. Biomed. Mater. Res. A 2020, 108, 2324-2350. [CrossRef]

30. Alzanbaki, H.; Moretti, M.; Hauser, C.A.E. Engineered Microgels-Their Manufacturing and Biomedical Applications. Micromachines 2021, 12, 45. [CrossRef] [PubMed]

31. Carratalá, J.V.; Serna, N.; Villaverde, A.; Vázquez, E.; Ferrer-Miralles, N. Nanostructured antimicrobial peptides: The last push towards clinics. Biotechnol. Adv. 2020, 44, 107603. [CrossRef] [PubMed]

32. Han, C.; Zhang, Z.; Sun, J.; Li, K.; Li, Y.; Ren, C.; Meng, Q.; Yang, J. Self-Assembling Peptide-Based Hydrogels in Angiogenesis. Int. J. Nanomed. 2020, 15, 10257-10269. [CrossRef] [PubMed]

33. Tarvirdipour, S.; Huang, X.; Mihali, V.; Schoenenberger, C.A.; Palivan, C.G. Peptide-Based Nanoassemblies in Gene Therapy and Diagnosis: Paving the Way for Clinical Application. Molecules 2020, 25, 3482. [CrossRef] [PubMed]

34. Castillo-Díaz, L.A.; Ruiz-Pacheco, J.A.; Elsawy, M.A.; Reyes-Martínez, J.E.; Enríquez-Rodríguez, A.I. Self-Assembling Peptides as an Emerging Platform for the Treatment of Metabolic Syndrome. Int. J. Nanomed. 2020, 15, 10349-10370. [CrossRef]

35. Petit, N.; Dyer, J.M.; Clerens, S.; Gerrard, J.A.; Domigan, L.J. Oral delivery of self-assembling bioactive peptides to target gastrointestinal tract disease. Food Funct. 2020, 11, 9468-9488. [CrossRef]

36. Chen, C.H.; Hsu, E.L.; Stupp, S.I. Supramolecular self-assembling peptides to deliver bone morphogenetic proteins for skeletal regeneration. Bone 2020, 141, 115565. [CrossRef]

37. Garifullin, R.; Guler, M.O. Electroactive peptide-based supramolecular polymers. Mater. Today Bio 2021, 10, 100099. [CrossRef]

38. Sharma, P.; Pal, V.K.; Roy, S. An overview of latest advances in exploring bioactive peptide hydrogels for neural tissue engineering. Biomater. Sci. 2021, 9, 3911-3938. [CrossRef]

39. Zhang, L.; Lu, J.R.; Waigh, T.A. Electronics of peptide- and protein-based biomaterials. Adv. Colloid Interface Sci. 2021, $287,102319$. [CrossRef]

40. O’Neill, C.L.; Shrimali, P.C.; Clapacs, Z.P.; Files, M.A.; Rudra, J.S. Peptide-Based Supramolecular Vaccine Systems. Acta Biomater. 2021. [CrossRef]

41. Görbitz, C.H. Nanotube formation by hydrophobic dipeptides. Chem. Eur. J. 2001, 7, 5153-5159. [CrossRef]

42. Kralj, S.; Bellotto, O.; Parisi, E.; Garcia, A.M.; Iglesias, D.; Semeraro, S.; Deganutti, C.; D' Andrea, P.; Vargiu, A.V.; Geremia, S.; et al . Heterochirality and Halogenation Control Phe-Phe Hierarchical Assembly. ACS Nano 2020, 14, 16951-16961. [CrossRef] [PubMed]

43. Aslam Khan, M.U.; Abd Razak, S.I.; Al Arjan, W.S.; Nazir, S.; Sahaya Anand, T.J.; Mehboob, H.; Amin, R. Recent Advances in Biopolymeric Composite Materials for Tissue Engineering and Regenerative Medicines: A Review. Molecules 2021, $26,619$. [CrossRef] [PubMed]

44. Pushpavanam, K.; Ma, J.; Cai, Y.; Naser, N.Y.; Baneyx, F. Solid-Binding Proteins: Bridging Synthesis, Assembly, and Function in Hybrid and Hierarchical Materials Fabrication. Annu. Rev. Chem. Biomol. Eng. 2021, 12, 333-357. [CrossRef] [PubMed]

45. Mondal, S.; Das, S.; Nandi, A.K. A review on recent advances in polymer and peptide hydrogels. Soft Matter 2020, 16, 1404-1454. [CrossRef] [PubMed]

46. Song, H.-Q.; Fan, Y.; Hu, Y.; Cheng, G.; Xu, F.-J. Polysaccharide-Peptide Conjugates: A Versatile Material Platform for Biomedical Applications. Adv. Funct. Mater. 2021, 31, 2005978. [CrossRef] 
47. Higashi, S.L.; Rozi, N.; Hanifah, S.A.; Ikeda, M. Supramolecular Architectures of Nucleic Acid/Peptide Hybrids. Int. J. Mol. Sci. 2020, 21, 9458. [CrossRef] [PubMed]

48. Bellotto, O.; Cringoli, M.C.; Perathoner, S.; Fornasiero, P.; Marchesan, S. Peptide Gelators to Template Inorganic Nanoparticle Formation. Gels 2021, 7, 14. [CrossRef]

49. Pigliacelli, C.; Sánchez-Fernández, R.; García, M.D.; Peinador, C.; Pazos, E. Self-assembled peptide-inorganic nanoparticle superstructures: From component design to applications. Chem. Commun. 2020, 56, 8000-8014. [CrossRef]

50. Gao, P.; Wu, Y.; Wu, L. Co-assembly of polyoxometalates and peptides towards biological applications. Soft Matter 2016, 12, 8464-8479. [CrossRef]

51. Kieffer, M.; Garcia, A.M.; Haynes, C.J.E.; Kralj, S.; Iglesias, D.; Nitschke, J.R.; Marchesan, S. Embedding and Positioning of Two FeII4L4 Cages in Supramolecular Tripeptide Gels for Selective Chemical Segregation. Angew. Chem. Int. Ed. 2019, 58, 7982-7986. [CrossRef] [PubMed]

52. Georgakilas, V.; Perman, J.A.; Tucek, J.; Zboril, R. Broad Family of Carbon Nanoallotropes: Classification, Chemistry, and Applications of Fullerenes, Carbon Dots, Nanotubes, Graphene, Nanodiamonds, and Combined Superstructures. Chem. Rev. 2015, 115, 4744-4822. [CrossRef] [PubMed]

53. McHedlov-Petrossyan, N.O. Fullerenes in Liquid Media: An Unsettling Intrusion into the Solution Chemistry. Chem. Rev. 2013, 113, 5149-5193. [CrossRef] [PubMed]

54. Silvia, G.; Adalberto, C.; Viviana, M. Carbon Nano-onions: A Valuable Class of Carbon Nanomaterials in Biomedicine. Curr. Med. Chem. 2019, 26, 6915-6929. [CrossRef]

55. Liu, J.; Li, R.; Yang, B. Carbon Dots: A New Type of Carbon-Based Nanomaterial with Wide Applications. ACS Centr. Sci. 2020, 6 , 2179-2195. [CrossRef]

56. Yang, F.; Wang, M.; Zhang, D.; Yang, J.; Zheng, M.; Li, Y. Chirality pure carbon nanotubes: Growth, sorting, and characterization. Chem. Rev. 2020, 120, 2693-2758. [CrossRef]

57. Bottari, G.; Herranz, M.; Wibmer, L.; Volland, M.; Rodríguez-Pérez, L.; Guldi, D.M.; Hirsch, A.; Martín, N.; D’Souza, F.; Torres, T. Chemical functionalization and characterization of graphene-based materials. Chem. Soc. Rev. 2017, 46, 4464-4500. [CrossRef]

58. Karousis, N.; Suarez-Martinez, I.; Ewels, C.P.; Tagmatarchis, N. Structure, Properties, Functionalization, and Applications of Carbon Nanohorns. Chem. Rev. 2016, 116, 4850-4883. [CrossRef]

59. Basso, L.; Cazzanelli, M.; Orlandi, M.; Miotello, A. Nanodiamonds: Synthesis and application in sensing, catalysis, and the possible connection with some processes occurring in space. Appl. Sci. 2020, 10, 4094. [CrossRef]

60. Bondon, N.; Raehm, L.; Charnay, C.; Boukherroub, R.; Durand, J.O. Nanodiamonds for bioapplications, recent developments. J. Mater. Chem. B 2020, 8, 10878-10896. [CrossRef]

61. Adorinni, S.; Cringoli, M.C.; Perathoner, S.; Fornasiero, P.; Marchesan, S. Green Approaches to Carbon Nanostructure-Based Biomaterials. Appl. Sci. 2021, 11, 2490. [CrossRef]

62. Ugarte, D. Onion-like graphitic particles. Carbon 1995, 33, 989-993. [CrossRef]

63. Piovesana, S.; Iglesias, D.; Melle-Franco, M.; Kralj, S.; Cavaliere, C.; Melchionna, M.; Laganà, A.; Capriotti, A.L.; Marchesan, S. Carbon nanostructure morphology templates nanocomposites for phosphoproteomics. Nano Res. 2020, 13, 380-388. [CrossRef]

64. Tonellato, M.; Piccione, M.; Gasparotto, M.; Bellet, P.; Tibaudo, L.; Vicentini, N.; Bergantino, E.; Menna, E.; Vitiello, L.; Di Liddo, R.; et al. Commitment of autologous human multipotent stem cells on biomimetic poly-l-lactic acid-based scaffolds is strongly influenced by structure and concentration of carbon nanomaterial. Nanomaterials 2020, 10, 415. [CrossRef]

65. Vicentini, N.; Gatti, T.; Salerno, M.; Hernandez Gomez, Y.S.; Bellon, M.; Gallio, S.; Marega, C.; Filippini, F.; Menna, E. Effect of different functionalized carbon nanostructures as fillers on the physical properties of biocompatible poly(L-lactic acid) composites. Mater. Chem. Phys. 2018, 214, 265-276. [CrossRef]

66. Iglesias, D.; Melle-Franco, M.; Kurbasic, M.; Melchionna, M.; Abrami, M.; Grassi, M.; Prato, M.; Marchesan, S. Oxidized Nanocarbons-Tripeptide Supramolecular Hydrogels: Shape Matters! ACS Nano 2018, 12, 5530-5538. [CrossRef] [PubMed]

67. Wang, J.; Zhu, Z.; Bortolini, C.; Hoffmann, S.V.; Amari, A.; Zhang, H.X.; Liu, L.; Dong, M.D. Dimensionality of carbon nanomaterial impacting on the modulation of amyloid peptide assembly. Nanotechnology 2016, 27, 304001. [CrossRef]

68. Pinals, R.L.; Yang, D.; Lui, A.; Cao, W.; Landry, M.P. Corona exchange dynamics on carbon nanotubes by multiplexed fluorescence monitoring. J. Am. Chem. Soc. 2019, 142, 1254-1264. [CrossRef] [PubMed]

69. Palmieri, V.; Perini, G.; De Spirito, M.; Papi, M. Graphene oxide touches blood: In Vivo interactions of bio-coronated 2D materials. Nanoscale Horiz. 2019, 4, 273-290. [CrossRef]

70. Duke, K.S.; Bonner, J.C. Mechanisms of carbon nanotube-induced pulmonary fibrosis: A physicochemical characteristic perspective. Wiley Int. Rev. Nanomed. Nanobiotechnol. 2018, 10, e1498. [CrossRef]

71. Chen, M.; Qin, X.; Zeng, G. Biodegradation of carbon nanotubes, graphene, and their derivatives. Trends Biotechnol. 2017, 35, 836-846. [CrossRef]

72. Keshavan, S.; Calligari, P.; Stella, L.; Fusco, L.; Delogu, L.G.; Fadeel, B. Nano-bio interactions: A neutrophil-centric view. Cell Death Dis. 2019, 10, 569. [CrossRef] [PubMed]

73. Cai, K.; Wang, A.Z.; Yin, L.; Cheng, J. Bio-nano interface: The impact of biological environment on nanomaterials and their delivery properties. J. Control. Release 2017, 263, 211-222. [CrossRef] [PubMed]

74. Panwar, N.; Soehartono, A.M.; Chan, K.K.; Zeng, S.; Xu, G.; Qu, J.; Coquet, P.; Yong, K.-T.; Chen, X. Nanocarbons for Biology and Medicine: Sensing, Imaging, and Drug Delivery. Chem. Rev. 2019, 119, 9559-9656. [CrossRef] 
75. Zhuang, W.R.; Wang, Y.; Cui, P.F.; Xing, L.; Lee, J.; Kim, D.; Jiang, H.L.; Oh, Y.K. Applications of $\pi-\pi$ stacking interactions in the design of drug-delivery systems. J. Control. Release 2019, 294, 311-326. [CrossRef] [PubMed]

76. Marchesan, S.; Melchionna, M.; Prato, M. Carbon Nanostructures for Nanomedicine: Opportunities and Challenges. Fuller. Nanotub. Carbon Nanostruct. 2014, 22, 190-195. [CrossRef]

77. Mehra, N.K.; Jain, A.K.; Nahar, M. Carbon nanomaterials in oncology: An expanding horizon. Drug Discov. Today 2018, 23, 1016-1025. [CrossRef] [PubMed]

78. Xin, Q.; Shah, H.; Nawaz, A.; Xie, W.; Akram, M.Z.; Batool, A.; Tian, L.; Jan, S.U.; Boddula, R.; Guo, B. Antibacterial carbon-based nanomaterials. Adv. Mater. 2019, 31, 1804838. [CrossRef] [PubMed]

79. Ku, S.H.; Lee, M.; Park, C.B. Carbon-based nanomaterials for tissue engineering. Adv. Healthc. Mater. 2013, 2, 244-260. [CrossRef] [PubMed]

80. Marchesan, S.; Ballerini, L.; Prato, M. Nanomaterials for stimulating nerve growth. Science 2017, 356, 1010-1011. [CrossRef] [PubMed]

81. Aydin, T.; Gurcan, C.; Taheri, H.; Yilmazer, A. Graphene Based Materials in Neural Tissue Regeneration. Adv. Exp. Med. Biol. 2018, 1107, 129-142. [CrossRef] [PubMed]

82. Marchesan, S.; Bosi, S.; Alshatwi, A.; Prato, M. Carbon nanotubes for organ regeneration: An electrifying performance. Nano Today 2016, 11, 398-401. [CrossRef]

83. Raja, A.; Rajasekaran, P.; Selvakumar, K.; Arivanandhan, M.; Asath Bahadur, S.; Swaminathan, M. Efficient Photoreduction of Hexavalent Chromium Using the Reduced Graphene Oxide-Sm(2)MoO(6)- $\mathrm{TiO}(2)$ Catalyst under Visible Light Illumination. ACS Omega 2020, 5, 6414-6422. [CrossRef]

84. Peng, Z.; Zhao, T.; Zhou, Y.; Li, S.; Li, J.; Leblanc, R.M. Bone Tissue Engineering via Carbon-Based Nanomaterials. Adv. Healthc. Mater. 2020, 9, e1901495. [CrossRef]

85. Sainio, S.; Leppänen, E.; Mynttinen, E.; Palomäki, T.; Wester, N.; Etula, J.; Isoaho, N.; Peltola, E.; Koehne, J.; Meyyappan, M. Integrating Carbon Nanomaterials with Metals for Bio-sensing Applications. Mol. Neurobiol. 2020, 57, 179-190. [CrossRef]

86. Loh, K.P.; Ho, D.; Chiu, G.N.C.; Leong, D.T.; Pastorin, G.; Chow, E.K.-H. Clinical Applications of Carbon Nanomaterials in Diagnostics and Therapy. Adv. Mater. 2018, 30, 1802368. [CrossRef]

87. Madannejad, R.; Shoaie, N.; Jahanpeyma, F.; Darvishi, M.H.; Azimzadeh, M.; Javadi, H. Toxicity of carbon-based nanomaterials: Reviewing recent reports in medical and biological systems. Chem. Biol. Interact. 2019, 307, 206-222. [CrossRef]

88. Gupta, N.; Rai, D.B.; Jangid, A.K.; Kulhari, H. A review of theranostics applications and toxicities of carbon nanomaterials. Curr. Drug Metab. 2019, 20, 506-532. [CrossRef]

89. Fadeel, B.; Kostarelos, K. Grouping all carbon nanotubes into a single substance category is scientifically unjustified. Nat. Nanotechnol. 2020, 15, 164. [CrossRef]

90. Graphene Standards. Available online: https://www.thegraphenecouncil.org/page/GrapheneStandards (accessed on 30 June 2021).

91. Xiarchos, I.; Morozinis, A.K.; Kavouras, P.; Charitidis, C.A. Nanocharacterization, Materials Modeling, and Research Integrity as Enablers of Sound Risk Assessment: Designing Responsible Nanotechnology. Small 2020, 16, 2001590. [CrossRef]

92. Romanos, N.; Kalogerini, M.; Koumoulos, E.P.; Morozinis, A.K.; Sebastiani, M.; Charitidis, C. Innovative Data Management in advanced characterization: Implications for materials design. Mater. Today Commun. 2019, 20, 100541. [CrossRef]

93. Kotzabasaki, M.; Sotiropoulos, I.; Charitidis, C.; Sarimveis, H. Machine learning methods for multi-walled carbon nanotubes (MWCNT) genotoxicity prediction. Nanoscale Adv. 2021, 3, 3167-3176. [CrossRef]

94. Tong, T.; Wang, L.; You, X.; Wu, J. Nano and microscale delivery platforms for enhanced oral peptide/protein bioavailability. Biomater. Sci. 2020, 8, 5804-5823. [CrossRef] [PubMed]

95. Katyal, P.; Mahmoudinobar, F.; Montclare, J.K. Recent trends in peptide and protein-based hydrogels. Curr. Opin. Struct. Biol. 2020, 63, 97-105. [CrossRef]

96. Iglesias, D.; Bosi, S.; Melchionna, M.; Da Ros, T.; Marchesan, S. The Glitter of Carbon Nanostructures in Hybrid/Composite Hydrogels for Medicinal Use. Curr. Top. Med. Chem. 2016, 16, 1976-1989. [CrossRef] [PubMed]

97. Speranza, G. Carbon Nanomaterials: Synthesis, Functionalization and Sensing Applications. Nanomaterials 2021, $11,967$. [CrossRef]

98. Sheikholeslam, M.; Wheeler, S.D.; Duke, K.G.; Marsden, M.; Pritzker, M.; Chen, P. Peptide and peptide-carbon nanotube hydrogels as scaffolds for tissue \& 3D tumor engineering. Acta Biomater. 2018, 69, 107-119. [CrossRef]

99. El-Mahdy, A.F.M.; Kuo, S.-W. Diphenylpyrenylamine-functionalized polypeptides: Secondary structures, aggregation-induced emission, and carbon nanotube dispersibility. RSC Adv. 2018, 8, 15266-15281. [CrossRef]

100. Garriga, R.; Jurewicz, I.; Seyedin, S.; Bardi, N.; Totti, S.; Matta-Domjan, B.; Velliou, E.G.; Alkhorayef, M.A.; Cebolla, V.L.; Razal, J.M.; et al. Multifunctional, biocompatible and pH-responsive carbon nanotube- and graphene oxide/tectomer hybrid composites and coatings. Nanoscale 2017, 9, 7791-7804. [CrossRef]

101. Lian, Z.; Ji, T. Functional peptide-based drug delivery systems. J. Mater. Chem. B 2020, 8, 6517-6529. [CrossRef]

102. Khan, M.M.; Filipczak, N.; Torchilin, V.P. Cell penetrating peptides: A versatile vector for co-delivery of drug and genes in cancer. J. Control. Release 2021, 330, 1220-1228. [CrossRef]

103. Jin, J.; Wu, Y.; Chen, J.; Shen, Y.; Zhang, L.; Zhang, H.; Chen, L.; Yuan, H.; Chen, H.; Zhang, W.; et al. The peptide PROTAC modality: A novel strategy for targeted protein ubiquitination. Theranostics 2020, 10, 10141-10153. [CrossRef] [PubMed] 
104. Maity, D. Selected peptide-based fluorescent probes for biological applications. Beilstein J. Org. Chem. 2020, 16, $2971-2982$. [CrossRef]

105. Calvaresi, M.; Zerbetto, F. The Devil and Holy Water: Protein and Carbon Nanotube Hybrids. Acc. Chem. Res. 2013, 46, 2454-2463. [CrossRef]

106. Henna, T.K.; Raphey, V.R.; Sankar, R.; Ameena Shirin, V.K.; Gangadharappa, H.V.; Pramod, K. Carbon nanostructures: The drug and the delivery system for brain disorders. Int. J. Pharm. 2020, 587, 119701. [CrossRef]

107. Zhang, X.; Gong, C.; Akakuru, O.U.; Su, Z.; Wu, A.; Wei, G. The design and biomedical applications of self-assembled twodimensional organic biomaterials. Chem. Soc. Rev. 2019, 48, 5564-5595. [CrossRef]

108. Gholami, A.; Hashemi, S.A.; Yousefi, K.; Mousavi, S.M.; Chiang, W.-H.; Ramakrishna, S.; Mazraedoost, S.; Alizadeh, A.; Omidifar N.; Behbudi, G.; et al. 3D Nanostructures for Tissue Engineering, Cancer Therapy, and Gene Delivery. J. Nanomater. 2020, 2020, 1852946. [CrossRef]

109. Mazzier, D.; Carraro, F.; Crisma, M.; Rancan, M.; Toniolo, C.; Moretto, A. A terminally protected dipeptide: From crystal structure and self-assembly, through co-assembly with carbon-based materials, to a ternary catalyst for reduction chemistry in water. Soft Matter 2016, 12, 238-245. [CrossRef] [PubMed]

110. Garriga, R.; Jurewicz, I.; Seyedin, S.; Tripathi, M.; Pearson, J.R.; Cebolla, V.L.; Dalton, A.B.; Razal, J.M.; Muñoz, E. Two-dimensional oligoglycine tectomer adhesives for graphene oxide fiber functionalization. Carbon 2019, 147, 460-475. [CrossRef]

111. Li, Y.; Zhang, W.; Zhang, L.; Li, J.; Su, Z.; Wei, G. Sequence-Designed Peptide Nanofibers Bridged Conjugation of Graphene Quantum Dots with Graphene Oxide for High Performance Electrochemical Hydrogen Peroxide Biosensor. Adv. Mater. Interfaces 2017, 4, 1600895. [CrossRef]

112. Liu, Z.; Zou, Y.; Zhang, Q.; Chen, P.; Liu, Y.; Qian, Z. Distinct Binding Dynamics, Sites and Interactions of Fullerene and Fullerenols with Amyloid- $\beta$ Peptides Revealed by Molecular Dynamics Simulations. Int. J. Mol. Sci. 2019, 20, 2048. [CrossRef] [PubMed]

113. Sun, Y.; Qian, Z.; Wei, G. The inhibitory mechanism of a fullerene derivative against amyloid- $\beta$ peptide aggregation: An atomistic simulation study. Phys. Chem. Chem. Phys. 2016, 18, 12582-12591. [CrossRef] [PubMed]

114. Lamas, A.; Guerra, A.; Amorín, M.; Granja, J.R. New self-assembling peptide nanotubes of large diameter using $\delta$-amino acids. Chem. Sci. 2018, 9, 8228-8233. [CrossRef] [PubMed]

115. Zhang, Y.; Zhang, H.; Zou, Q.; Xing, R.; Jiao, T.; Yan, X. An injectable dipeptide-fullerene supramolecular hydrogel for photodynamic antibacterial therapy. J. Mater. Chem. B 2018, 6, 7335-7342. [CrossRef]

116. Cringoli, M.C.; Kralj, S.; Kurbasic, M.; Urban, M.; Marchesan, S. Luminescent supramolecular hydrogels from a tripeptide and nitrogen-doped carbon nanodots. Beilstein J. Nanotechnol. 2017, 8, 1553-1562. [CrossRef]

117. Chung, Y.J.; Lee, B.I.; Park, C.B. Multifunctional carbon dots as a therapeutic nanoagent for modulating Cu(II)-mediated $\beta$-amyloid aggregation. Nanoscale 2019, 11, 6297-6306. [CrossRef]

118. Chung, Y.J.; Lee, C.H.; Lim, J.; Jang, J.; Kang, H.; Park, C.B. Photomodulating Carbon Dots for Spatiotemporal Suppression of Alzheimer's $\beta$-Amyloid Aggregation. ACS Nano 2020, 14, 16973-16983. [CrossRef]

119. Huang, H.; Li, P.; Zhang, M.; Yu, Y.; Huang, Y.; Gu, H.; Wang, C.; Yang, Y. Graphene quantum dots for detecting monomeric amyloid peptides. Nanoscale 2017, 9, 5044-5048. [CrossRef]

120. Wang, Y.; Kadiyala, U.; Qu, Z.; Elvati, P.; Altheim, C.; Kotov, N.A.; Violi, A.; VanEpps, J.S. Anti-Biofilm Activity of Graphene Quantum Dots via Self-Assembly with Bacterial Amyloid Proteins. ACS Nano 2019, 13, 4278-4289. [CrossRef]

121. Su, Z.; Shen, H.; Wang, H.; Wang, J.; Li, J.; Nienhaus, G.U.; Shang, L.; Wei, G. Motif-Designed Peptide Nanofibers Decorated with Graphene Quantum Dots for Simultaneous Targeting and Imaging of Tumor Cells. Adv. Funct. Mater. 2015, 25, 5472-5478. [CrossRef]

122. He, L.; Xiao, Q.; Zhao, Y.; Li, J.; Reddy, S.; Shi, X.; Su, X.; Chiu, K.; Ramakrishna, S. Engineering an Injectable Electroactive Nanohybrid Hydrogel for Boosting Peripheral Nerve Growth and Myelination in Combination with Electrical Stimulation. ACS Appl. Mater. Interfaces 2020, 12, 53150-53163. [CrossRef]

123. Dinesh, B.; Squillaci, M.A.; Ménard-Moyon, C.; Samorì, P.; Bianco, A. Self-assembly of diphenylalanine backbone homologues and their combination with functionalized carbon nanotubes. Nanoscale 2015, 7, 15873-15879. [CrossRef]

124. Rehak, P.; Král, P. Hybridization of Biomolecular Crystals and Low-Dimensional Materials. ACS Nano 2021, 15, 6678-6683. [CrossRef]

125. Guilbaud-Chéreau, C.; Dinesh, B.; Schurhammer, R.; Collin, D.; Bianco, A.; Ménard-Moyon, C. Protected Amino Acid-Based Hydrogels Incorporating Carbon Nanomaterials for Near-Infrared Irradiation-Triggered Drug Release. ACS Appl. Mater. Interfaces 2019, 11, 13147-13157. [CrossRef]

126. Rissanou, A.N.; Keliri, A.; Arnittali, M.; Harmandaris, V. Self-assembly of diphenylalanine peptides on graphene via detailed atomistic simulations. Phys. Chem. Chem. Phys. 2020, 22, 27645-27657. [CrossRef] [PubMed]

127. Khatayevich, D.; Page, T.; Gresswell, C.; Hayamizu, Y.; Grady, W.; Sarikaya, M. Selective Detection of Target Proteins by Peptide-Enabled Graphene Biosensor. Small 2014, 10, 1505-1513. [CrossRef] [PubMed]

128. Thodkar, K.; Cazade, P.-A.; Bergmann, F.; Lopez-Calle, E.; Thompson, D.; Heindl, D. Self-Assembled Pyrene Stacks and Peptide Monolayers Tune the Electronic Properties of Functionalized Electrolyte-Gated Graphene Field-Effect Transistors. ACS Appl. Mater. Interfaces 2021, 13, 9134-9142. [CrossRef]

129. Li, P.; Sakuma, K.; Tsuchiya, S.; Sun, L.; Hayamizu, Y. Fibroin-like Peptides Self-Assembling on Two-Dimensional Materials as a Molecular Scaffold for Potential Biosensing. ACS Appl. Mater. Interfaces 2019, 11, 20670-20677. [CrossRef] [PubMed] 
130. Li, K.; Zhang, Z.; Li, D.; Zhang, W.; Yu, X.; Liu, W.; Gong, C.; Wei, G.; Su, Z. Biomimetic ultralight, highly porous, shape-adjustable, and biocompatible 3D graphene minerals via incorporation of self-assembled peptide nanosheets. Adv. Funct. Mater. 2018, 28, 1056. [CrossRef]

131. Almohammed, S.; Zhang, F.; Rodriguez, B.J.; Rice, J.H. Electric Field-Induced Chemical Surface-Enhanced Raman Spectroscopy Enhancement from Aligned Peptide Nanotube-Graphene Oxide Templates for Universal Trace Detection of Biomolecules. J. Phys. Chem. Lett. 2019, 10, 1878-1887. [CrossRef]

132. Trapani, G.; Caruso, V.C.L.; Cucci, L.M.; Attanasio, F.; Tabbì, G.; Forte, G.; La Mendola, D.; Satriano, C. Graphene Oxide Nanosheets Tailored With Aromatic Dipeptide Nanoassemblies for a Tuneable Interaction With Cell Membranes. Front. Bioeng. Biotechnol. 2020, 8. [CrossRef]

133. Zhang, Q.; Zhang, D.; Xu, G.; Xu, Y.; Lu, Y.; Li, S.; Liu, Q. Spectroscopic detection of thrombin with peptides self-assembled on gold nanoparticles hybridized graphene oxide. Sens. Actuators B Chem. 2017, 242, 443-449. [CrossRef]

134. Castelletto, V.; Kaur, A.; Hamley, I.; Barnes, R.; Karatzas, K.; Hermida-Merino, D.; Swioklo, S.; Connon, C.; Stasiak, J.; Reza, M.; et al. Hybrid membrane biomaterials from self-assembly in polysaccharide and peptide amphiphile mixtures: Controllable structural and mechanical properties and antimicrobial activity. RSC Adv. 2017, 7, 8366-8375. [CrossRef]

135. Ligorio, C.; Zhou, M.; Wychowaniec, J.K.; Zhu, X.; Bartlam, C.; Miller, A.F.; Vijayaraghavan, A.; Hoyland, J.A.; Saiani, A. Graphene oxide containing self-assembling peptide hybrid hydrogels as a potential 3D injectable cell delivery platform for intervertebral disc repair applications. Acta Biomater. 2019, 92, 92-103. [CrossRef]

136. Wang, J.; Ouyang, Z.; Ren, Z.; Li, J.; Zhang, P.; Wei, G.; Su, Z. Self-assembled peptide nanofibers on graphene oxide as a novel nanohybrid for biomimetic mineralization of hydroxyapatite. Carbon 2015, 89, 20-30. [CrossRef]

137. Yang, J.-K.; Kwak, S.-Y.; Jeon, S.-J.; Lee, E.; Ju, J.-M.; Kim, H.-I.; Lee, Y.-S.; Kim, J.-H. Proteolytic disassembly of peptide-mediated graphene oxide assemblies for turn-on fluorescence sensing of proteases. Nanoscale 2016, 8, 12272-12281. [CrossRef] [PubMed]

138. Lei, W.-W.; Shi, L.-Y.; Li, H.; Li, C.-X.; Diao, Y.-F.; Zhang, Y.-L.; Ran, R. A novel self-assembled hybrid organogel of polypeptidebased block copolymers with inclusion of polypeptide-functionalized graphene. RSC Adv. 2017, 7, 1471-1479. [CrossRef]

139. Wychowaniec, J.K.; Iliut, M.; Zhou, M.; Moffat, J.; Elsawy, M.A.; Pinheiro, W.A.; Hoyland, J.A.; Miller, A.F.; Vijayaraghavan, A.; Saiani, A. Designing Peptide/Graphene Hybrid Hydrogels through Fine-Tuning of Molecular Interactions. Biomacromolecules 2018, 19, 2731-2741. [CrossRef] [PubMed]

140. Chetia, M.; Debnath, S.; Chowdhury, S.; Chatterjee, S. Self-assembly and multifunctionality of peptide organogels: Oil spill recovery, dye absorption and synthesis of conducting biomaterials. RSC Adv. 2020, 10, 5220-5233. [CrossRef]

141. Eckhart, K.E.; Holt, B.D.; Laurencin, M.G.; Sydlik, S.A. Covalent conjugation of bioactive peptides to graphene oxide for biomedical applications. Biomater. Sci. 2019, 7, 3876-3885. [CrossRef]

142. Yao, S.; Yuan, X.; Jiang, L.; Xiong, T.; Zhang, J. Recent Progress on Fullerene-Based Materials: Synthesis, Properties, Modifications, and Photocatalytic Applications. Materials 2020, 13, 2924. [CrossRef]

143. Antoku, D.; Sugikawa, K.; Ikeda, A. Photodynamic Activity of Fullerene Derivatives Solubilized in Water by Natural-ProductBased Solubilizing Agents. Chem. Eur. J. 2019, 25, 1854-1865. [CrossRef] [PubMed]

144. Galvan, Y.P.; Alperovich, I.; Zolotukhin, P.; Prazdnova, E.; Mazanko, M.; Belanova, A.; Chistyakov, V. Fullerenes as Anti-Aging Antioxidants. Curr. Aging Sci. 2017, 10, 56-67. [CrossRef]

145. Akhtar, M.J.; Ahamed, M.; Alhadlaq, H.A.; Alshamsan, A. Mechanism of ROS scavenging and antioxidant signalling by redox metallic and fullerene nanomaterials: Potential implications in ROS associated degenerative disorders. Biochim. Biophys. Acta 2017, 1861, 802-813. [CrossRef] [PubMed]

146. Hamblin, M.R. Antimicrobial photodynamic inactivation: A bright new technique to kill resistant microbes. Curr. Opin. Microbiol. 2016, 33, 67-73. [CrossRef]

147. Kazemzadeh, H.; Mozafari, M. Fullerene-based delivery systems. Drug Discov. Today 2019, 24, 898-905. [CrossRef] [PubMed]

148. Kumar, M.; Raza, K. C60-fullerenes as Drug Delivery Carriers for Anticancer Agents: Promises and Hurdles. Pharm. Nanotechnol. 2017, 5, 169-179. [CrossRef]

149. Zhao, Y.; Shen, X.; Ma, R.; Hou, Y.; Qian, Y.; Fan, C. Biological and biocompatible characteristics of fullerenols nanomaterials for tissue engineering. Histol. Histopathol. 2021. [CrossRef]

150. Szymański, M.P.; Czajka, J.S.; Cmoch, P.; Iwanek, W.; Szumna, A. Interlaced capsules by self-assembly of cavitands substituted with tripeptides and tetrapeptides. Supramol. Chem. 2018, 30, 430-437. [CrossRef]

151. Bjelaković, M.; Kop, T.; Maslak, V.; Milić, D. Synthesis and characterization of highly ordered self-assembled bioactive fulleropeptides. J. Mater. Sci. 2016, 51, 739-747. [CrossRef]

152. Bjelaković, M.S.; Kop, T.J.; Đorđević, J.; Milić, D.R. Fulleropeptide esters as potential self-assembled antioxidants. Beilstein J. Nanotechnol. 2015, 6, 1065-1071. [CrossRef]

153. Zhou, Y.; Mintz, K.J.; Sharma, S.K.; Leblanc, R.M. Carbon Dots: Diverse Preparation, Application, and Perspective in Surface Chemistry. Langmuir 2019, 35, 9115-9132. [CrossRef] [PubMed]

154. Chung, Y.J.; Kim, J.; Park, C.B. Photonic Carbon Dots as an Emerging Nanoagent for Biomedical and Healthcare Applications. ACS Nano 2020, 14, 6470-6497. [CrossRef] [PubMed]

155. Anwar, S.; Ding, H.; Xu, M.; Hu, X.; Li, Z.; Wang, J.; Liu, L.; Jiang, L.; Wang, D.; Dong, C.; et al. Recent Advances in Synthesis, Optical Properties, and Biomedical Applications of Carbon Dots. ACS Appl. Bio Mater. 2019, 2, 2317-2338. [CrossRef] 
156. Ji, C.; Zhou, Y.; Leblanc, R.M.; Peng, Z. Recent Developments of Carbon Dots in Biosensing: A Review. ACS Sens. 2020, 5, 2724-2741. [CrossRef] [PubMed]

157. Apter, B.; Lapshina, N.; Barhom, H.; Fainberg, B.; Handelman, A.; Accardo, A.; Diaferia, C.; Ginzburg, P.; Morelli, G.; Rosenman, G. Fluorescence Phenomena in Amyloid and Amyloidogenic Bionanostructures. Crystals 2020, 10, 668. [CrossRef]

158. Kosolapova, A.O.; Antonets, K.S.; Belousov, M.V.; Nizhnikov, A.A. Biological Functions of Prokaryotic Amyloids in Interspecies Interactions: Facts and Assumptions. Int. J. Mol. Sci. 2020, 21, 7240. [CrossRef] [PubMed]

159. Tasis, D.; Tagmatarchis, N.; Bianco, A.; Prato, M. Chemistry of Carbon Nanotubes. Chem. Rev. 2006, 106, 1105-1136. [CrossRef]

160. Yomogida, Y.; Tanaka, T.; Tsuzuki, M.; Wei, X.; Kataura, H. Chirality Pure Carbon Nanotubes: Growth, Sorting, and Characterization. ACS Appl. Nano Mater. 2020, 3, 11289-11297. [CrossRef]

161. Bati, A.S.R.; Yu, L.; Batmunkh, M.; Shapter, J.G. Recent Advances in Applications of Sorted Single-Walled Carbon Nanotubes. Adv. Funct. Mater. 2019, 29, 1902273. [CrossRef]

162. He, M.; Zhang, S.; Zhang, J. Horizontal single-walled carbon nanotube arrays: Controlled synthesis, characterizations, and applications. Chem. Rev. 2020, 120, 12592-12684. [CrossRef] [PubMed]

163. Feng, J.; Chen, C.; Sun, X.; Peng, H. Implantable Fiber Biosensors Based on Carbon Nanotubes. Acc. Mater. Res. 2021, 2, $138-146$. [CrossRef]

164. Mikhalchan, A.; Vilatela, J.J. A perspective on high-performance CNT fibres for structural composites. Carbon 2019, 150, 191-215. [CrossRef]

165. Zhang, X.; Lu, W.; Zhou, G.; Li, Q. Understanding the Mechanical and Conductive Properties of Carbon Nanotube Fibers for Smart Electronics. Adv. Mater. 2020, 32, 1902028. [CrossRef]

166. Iglesias, D.; Senokos, E.; Alemán, B.; Cabana, L.; Navío, C.; Marcilla, R.; Prato, M.; Vilatela, J.J.; Marchesan, S. Gas-Phase Functionalization of Macroscopic Carbon Nanotube Fiber Assemblies: Reaction Control, Electrochemical Properties, and Use for Flexible Supercapacitors. ACS Appl. Mater. Interfaces 2018, 10, 5760-5770. [CrossRef]

167. Anaya-Plaza, E.; Shaukat, A.; Lehtonen, I.; Kostiainen, M.A. Biomolecule-Directed Carbon Nanotube Self-Assembly. Adv. Healthc. Mater. 2021, 10, 2001162. [CrossRef]

168. Kang, N.; Hua, J.; Gao, L.; Zhang, B.; Pang, J. The Interplay between Whey Protein Fibrils with Carbon Nanotubes or Carbon Nano-Onions. Materials 2021, 14, 608. [CrossRef]

169. Zhang, N.; Yeo, J.; Lim, Y.; Guan, P.; Zeng, K.; Hu, X.; Cheng, Y. Tuning the structure of monomeric amyloid beta peptide by the curvature of carbon nanotubes. Carbon 2019, 153, 717-724. [CrossRef]

170. Antonucci, A.; Kupis-Rozmysłowicz, J.; Boghossian, A.A. Noncovalent Protein and Peptide Functionalization of Single-Walled Carbon Nanotubes for Biodelivery and Optical Sensing Applications. ACS Appl. Mater. Interfaces 2017, 9, 11321-11331. [CrossRef] [PubMed]

171. de la Zerda, A.; Bodapati, S.; Teed, R.; May, S.Y.; Tabakman, S.M.; Liu, Z.; Khuri-Yakub, B.T.; Chen, X.; Dai, H.; Gambhir, S.S. Family of Enhanced Photoacoustic Imaging Agents for High-Sensitivity and Multiplexing Studies in Living Mice. ACS Nano 2012, 6, 4694-4701. [CrossRef]

172. Wick, P.; Louw-Gaume, A.E.; Kucki, M.; Krug, H.F.; Kostarelos, K.; Fadeel, B.; Dawson, K.A.; Salvati, A.; Vázquez, E.; Ballerini, L. Classification framework for graphene-based materials. Angew. Chem. Int. Ed. 2014, 53, 7714-7718. [CrossRef]

173. Catania, F.; Marras, E.; Giorcelli, M.; Jagdale, P.; Lavagna, L.; Tagliaferro, A.; Bartoli, M. A Review on Recent Advancements of Graphene and Graphene-Related Materials in Biological Applications. Appl. Sci. 2021, 11, 614. [CrossRef]

174. Bellet, P.; Gasparotto, M.; Pressi, S.; Fortunato, A.; Scapin, G.; Mba, M.; Menna, E.; Filippini, F. Graphene-Based Scaffolds for Regenerative Medicine. Nanomaterials 2021, 11, 404. [CrossRef] [PubMed]

175. Dasetty, S.; Sarupria, S. Advancing Rational Control of Peptide-Surface Complexes. J. Phys. Chem. B 2021, $125,2644-2657$. [CrossRef]

176. Bolat, G.; Akbal Vural, O.; Tugce Yaman, Y.; Abaci, S. Label-free impedimetric miRNA-192 genosensor platform using graphene oxide decorated peptide nanotubes composite. Microchem. J. 2021, 166, 106218. [CrossRef]

177. Shang, G.; Mi, Y.; Mei, Y.; Wang, G.; Wang, Y.; Li, X.; Wang, Y.; Li, Y.; Zhao, G. MicroRNA-192 inhibits the proliferation, migration and invasion of osteosarcoma cells and promotes apoptosis by targeting matrix metalloproteinase-11. Oncol. Lett. 2018, 15, 7265-7272. [CrossRef] [PubMed]

178. Nguyen, V.; Zhu, R.; Jenkins, K.; Yang, R. Self-assembly of diphenylalanine peptide with controlled polarization for power generation. Nat. Commun. 2016, 7, 13566. [CrossRef]

179. Almohammed, S.; Thampi, A.; Bazaid, A.; Zhang, F.; Moreno, S.; Keogh, K.; Minary-Jolandan, M.; Rice, J.H.; Rodriguez, B.J. Energy harvesting with peptide nanotube-graphene oxide flexible substrates prepared with electric field and wettability assisted self-assembly. J. Appl. Phys. 2020, 128, 115101. [CrossRef]

180. Joshi, S.; Siddiqui, R.; Sharma, P.; Kumar, R.; Verma, G.; Saini, A. Green synthesis of peptide functionalized reduced graphene oxide (rGO) nano bioconjugate with enhanced antibacterial activity. Sci. Rep. 2020, 10, 9441. [CrossRef]

181. Eckhart, K.E.; Starvaggi, F.A.; Sydlik, S.A. One-Shot Synthesis of Peptide Amphiphiles with Applications in Directed Graphenic Assembly. Biomacromolecules 2020, 21, 3878-3886. [CrossRef]

182. Schnaider, L.; Brahmachari, S.; Schmidt, N.W.; Mensa, B.; Shaham-Niv, S.; Bychenko, D.; Adler-Abramovich, L.; Shimon, L.J.W.; Kolusheva, S.; DeGrado, W.F.; et al. Self-assembling dipeptide antibacterial nanostructures with membrane disrupting activity. Nat. Commun. 2017, 8, 1365. [CrossRef] 
183. Balu, R.; Dorishetty, P.; Mata, J.P.; Hill, A.J.; Dutta, N.K.; Choudhury, N.R. Tuning the Hierarchical Structure and Resilience of Resilin-like Polypeptide Hydrogels Using Graphene Oxide. ACS Appl. Bio Mater. 2020, 3, 8688-8697. [CrossRef]

184. Giuri, D.; Barbalinardo, M.; Zanna, N.; Paci, P.; Montalti, M.; Cavallini, M.; Valle, F.; Calvaresi, M.; Tomasini, C. Tuning Mechanical Properties of Pseudopeptide Supramolecular Hydrogels by Graphene Doping. Molecules 2019, 24, 4345. [CrossRef] [PubMed]

185. Jiang, Y.; Deng, Y.; Zhang, B.; Hua, W.; Wang, X.; Qi, Q.; Lin, Q.; Lv, W. An interlayer composed of a porous carbon sheet embedded with TiO2 nanoparticles for stable and high rate lithium-sulfur batteries. Nanoscale 2020, 12, 12308-12316. [CrossRef] [PubMed]

186. Pinotsi, D.; Grisanti, L.; Mahou, P.; Gebauer, R.; Kaminski, C.F.; Hassanali, A.; Kaminski Schierle, G.S. Proton Transfer and Structure-Specific Fluorescence in Hydrogen Bond-Rich Protein Structures. J. Am. Chem. Soc. 2016, 138, 3046-3057. [CrossRef] [PubMed] 